\title{
Synthetic Studies on Novel 1,4-Dihydro-2-methylthio-4,4,6-trisubstituted Pyrimidine-5-carboxylic Acid Esters and Their Tautomers
}

\author{
Yoshio Nishimura, ${ }^{*, a}$ Yasuko Okamoto, ${ }^{b}$ Masaya Ikunake, ${ }^{a}$ and Yoshihiko Ohyama ${ }^{a}$ \\ ${ }^{a}$ Department of Pharmaceutical Chemistry, Faculty of Pharmacy, Yasuda Women's University; 6-13-1 Yasuhigashi, \\ Asaminami-ku, Hiroshima 731-0153, Japan: and ${ }^{b}$ Faculty of Pharmaceutical Sciences, Tokushima Bunri University; \\ Yamashiro-cho, Tokushima 770-8514, Japan.
}

Received June 22, 2011; accepted September 22, 2011; published online October 4, 2011

A mixture of alkyl 1,4-dihydro-2-methylthio-4,4,6-trisubstituted pyrimidine-5-carboxylate 1 and its tautomeric isomer, alkyl 1,6-dihydro-2-methylthio-4,6,6-trisubstituted pyrimidine-5-carboxylate 2 is synthesized by the Atwal--Biginelli cyclocondensation reaction of $S$-methylisothiourea hemisulfate salt 3 with 2 -(gem-disubstituted)methylene-3-oxoesters 4 that can be accessed by the Lehnert procedure for the Knoevenagel-type condensation. The structures of the tautomeric products of the Atwal-Biginelli cyclocondensation reaction, 1 and 2, which are inseparable from each other, are determined unambiguously by ${ }^{1} \mathrm{H}-\mathrm{NMR}$ spectroscopy at various temperatures and nuclear Overhauser enhancement spectroscopy (NOESY) experiment. Because these dihydropyrimidine products are otherwise inaccessible and thus hitherto unavailable, the synthetic methods established in this study will help to expand the molecular diversity of their related derivatives.

Key words Atwal-Biginelli reaction; 2-(gem-disubstituted methylene)-3-oxoester; tautomer; alkyl 1,4-dihydro-2-methylthio4,4,6-trisubstituted pyrimidine-5-carboxylate; alkyl 1,6-dihydro-2-methylthio-4,6,6-trisubstituted pyrimidine-5-carboxylate

This article deals with a general approach to synthesizing alkyl 1,4-dihydro-2-methylthio-4,4,6-trisubstituted pyrimidine-5-carboxylate 1 and its tautomeric isomer, alkyl 1,6dihydro-2-methylthio-4,6,6-trisubstituted pyrimidine-5-carboxylate 2, which was achieved by applying the Atwal-Biginelli cyclocondensation reaction ${ }^{1-3)}$ of $S$-methylisothiourea hemisulfate salt 3 to 2-(gem-disubstituted)methylene-3-oxoesters 4 available by the Lehnert procedure ${ }^{4,5)}$ for the Knoevenagel-type condensation (Fig. 1). This synthetic study was conducted as part of our medicinal chemistry program to explore alkyl 3,4-dihydro-2-oxo-3,4,4,6-tetrasubstituted pyrimidine-5-carboxylates $\mathbf{5 a}$ and their 2-thioxo congeners 5b for novel therapeutic agents, ${ }^{6}$ ) which was inspired by the two track records with the related 1,4-dihydro-4-monoaryl-6methylpyrimidine derivatives that follow: $(R)$-SQ $32926 \mathbf{6}^{7)}$ a calcium channel blocker developed as an orally active antihypertensive agent, and monastrol $7,{ }^{8-10)}$ a possible anticancer agent that inhibits mitotic cell division by blocking the activity of kinesin Eg 5, a motor protein causing spindle bipolarity.

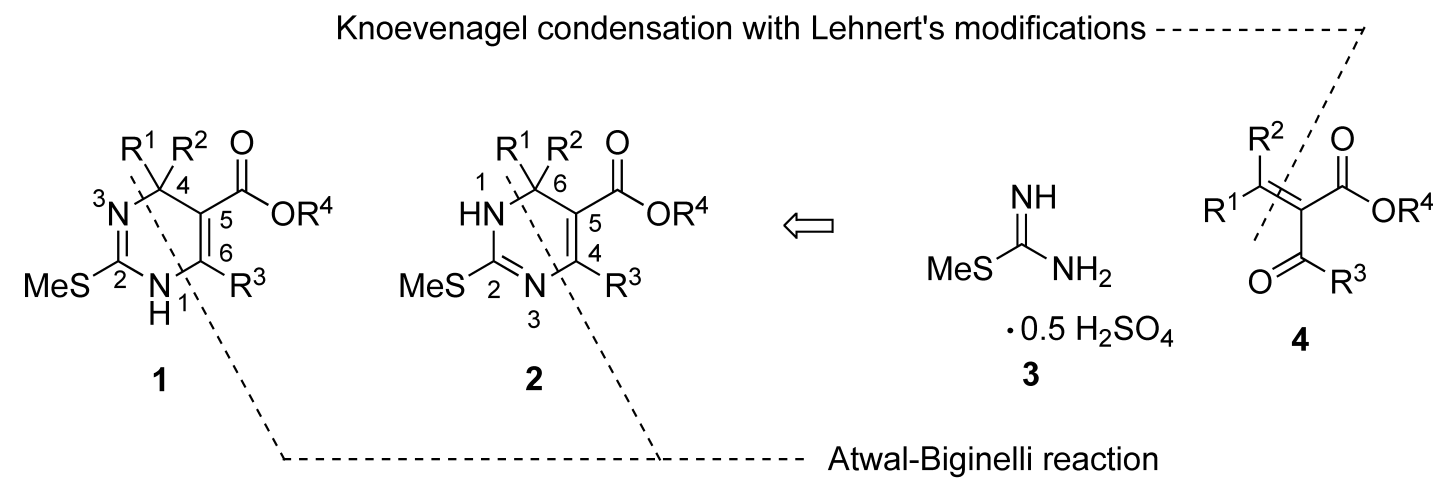

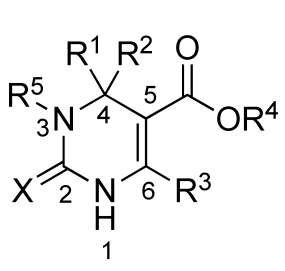

5a $X=0$

b $X=S$<smiles></smiles>

(R)-SQ 329266<smiles>CCOC(=O)C1=C(C)NC(=S)N[C@H]1c1cccc(O)c1</smiles>

monastrol 7

Fig. 1. Synthetic Approach to Alkyl 1,4-Dihydro-2-methylthio-4,4,6-trisubstituted Pyrimidine-5-carboxylate $\mathbf{1}$ and Its Tautomeric Isomer $\mathbf{2}$ and Structures of Related 2-Oxo and 2-Thioxo Analogs 


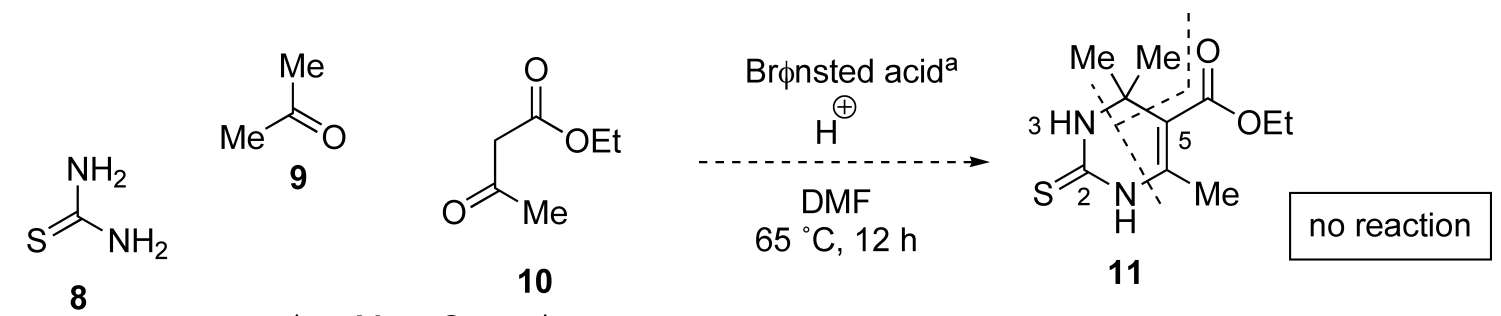<smiles>CCOC(=O)C(C(C)=O)=C(C)C</smiles>

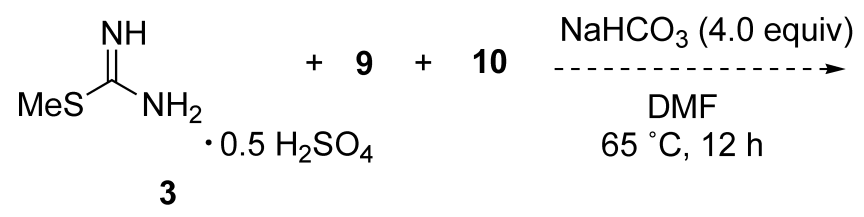

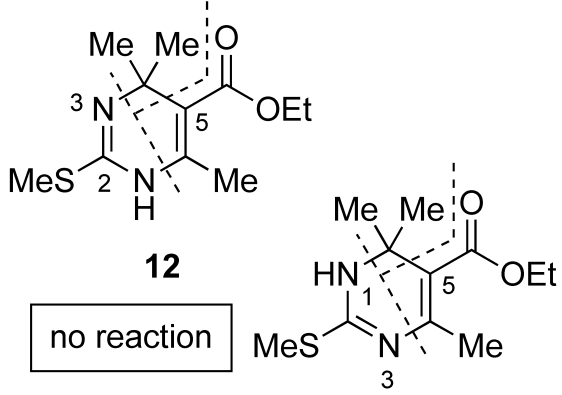

a) For the Bronsted acid employed see text.

Chart 1. Three-Component Biginelli Reaction<smiles>CCOC(=O)C(=Cc1ccccc1)C(C)=O</smiles><smiles>CCOC(=O)C1=C(C)NC(S(C)(=O)=O)=NC1(c1ccccc1)c1ccccc1</smiles>

$(67 \%)$

Chart 2. Typical Atwal-Biginelli Cyclocondensation Reaction to Afford Alkyl 1,4-Dihydro-2-methylthio-4,6-disubstituted Pyrimidine-5-carboxylate 15 and Its Tautomeric Isomer 16

\section{Results and Discussion}

One of the ultimate synthetic targets being 3,4-dihydro4,4,6-trisubstituted-2-thioxopyrimidine $\mathbf{5 b}\left(\mathrm{R}^{5}=\mathrm{H}\right)$, a threecomponent Biginelli reaction was first attempted, in which ethyl acetoacetate (10 1.0 eq) was treated with thiourea 8 (1.2 eq) and acetone 9 (3-10 eq) in dimethylformamide (DMF) at $65^{\circ} \mathrm{C}$ for $12 \mathrm{~h}$ in the presence of a Brønsted acid (1.0 eq), such as $\mathrm{HCl}, \mathrm{H}_{2} \mathrm{SO}_{4}$, trifluoroacetic acid, 4-toluenesulfonic acid, or methanesulfonic acid (Chart 1). ${ }^{11)}$ However, no desired ethyl 3,4-dihydro-4,4,6-trimethyl-2-thioxopyrimidine-5-carboxylate $\mathbf{1 1}$ was produced, and the starting material 10 was recovered intact. Furthermore, no such threecomponent reaction took place to afford ethyl 1,4-dihydro4,6,6-trimethyl-2-methylthiopyrimidine-5-carboxylate $\mathbf{1 2}$ or its 1,6-dihydro tautomer $\mathbf{1 3}$ when $\mathbf{9}$ (3-10 eq) and $\mathbf{1 0}$ $(1.0 \mathrm{eq})$ were exposed to 3 (1.2 eq) instead of 8 in DMF in the presence of $\mathrm{NaHCO}_{3}(4.0 \mathrm{eq})$ at $65^{\circ} \mathrm{C}$ for $12 \mathrm{~h}^{12-14)}$

In contrast, when ethyl 2-benzylidene-3-oxobutanoate $\mathbf{1 4}$ $[E / Z(1: 3.0)],{ }^{15)}$ a typical 2-(monosubstituted)methylene-3oxoester prepared under the conventional Knoevenagel reaction conditions, was subjected to Atwal-Biginelli conditions
[3 (1.2 eq), $\mathrm{NaHCO}_{3}(4.0 \mathrm{eq}), \mathrm{DMF}, 60^{\circ} \mathrm{C}$ for $5 \mathrm{~h}$ ], the cyclocondensation reaction proceeded uneventfully to provide ethyl 1,4-dihydro-2-methylthio-4,6-disubstituted pyrimidine5-carboxylate $\mathbf{1 5}$ and its tautomeric isomer $\mathbf{1 6}$ as an inseparable mixture [15/16 $(2.2: 1)]$ in a combined yield of $67 \%$ (Chart 2). ${ }^{16,17)}$ Structural assignments for $\mathbf{1 5}$ and $\mathbf{1 6}$ were made by the following nuclear Overhauser enhancement spectroscopy (NOESY) experiment. With the major component 15, its 6-methyl protons exhibited a significant nuclear Overhauser effect (NOE) when the 1-NH proton was irradiated; hence, its structure was determined to be 1,4-dihydropyrimidine $\mathbf{1 5}$ as depicted in Chart 2. Irradiation of the 1NH proton in the minor component $\mathbf{1 6}$ caused the NOE on the 6-proton, which led to its structure being determined to be 1,6-dihydropyrimidine $\mathbf{1 6}$, a tautomeric isomer of $\mathbf{1 5}$ (Chart 2): for detail, see Experimental. Hence, it was envisioned that when prefabricated ethyl 3-oxo-2-(2-propylidene)-butanoate $\mathbf{1 7}$ was allowed to react with $\mathbf{8}$ and $\mathbf{3}$, the cyclocondensation in question should proceed to give $\mathbf{1 1}$ and a mixture of $\mathbf{1 2}$ and $\mathbf{1 3}$, respectively (Chart 1).

To test the above-mentioned proposition, $\mathbf{1 7}$ was required 


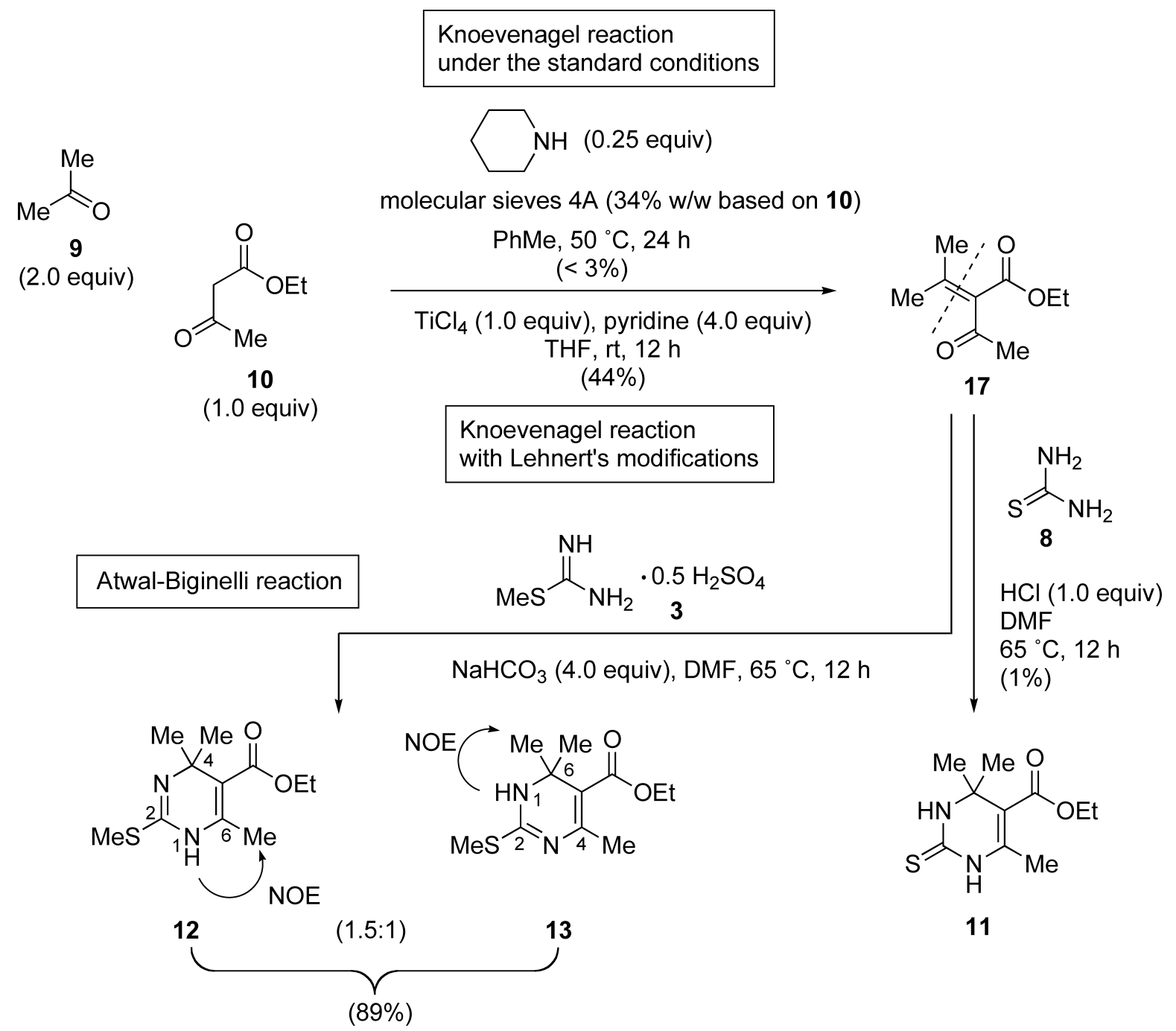

Chart 3. Synthesis of Ethyl 1,4-Dihydro-4,4,6-trimethyl-2-methylthiopyrimidine-5-carboxylate 12 and Its 1,6-Dihydro Tautomer 13

in sufficient quantity. To our disappointment, it was obtained in less than $3 \%$ yield when ethyl acetoacetate 10 (1.0 eq) and acetone 9 (2.0 eq) were subjected to the conventional Knoevenagel reaction conditions [piperidine $(0.25 \mathrm{eq})$, molecular sieves $4 \mathrm{~A}(34 \% \mathrm{w} / \mathrm{w}$ based on 10$)$, toluene, $\left.50{ }^{\circ} \mathrm{C}, 24 \mathrm{~h}\right]$ (Chart 3). ${ }^{18)}$ However, literature search in parallel with failed experimentation led to identifying the Lehnert's report, ${ }^{19-24)}$ which was demonstrated to be the most effective means of preparing 17 by the Knoevenagel-type condensation: when 10 (1.0 eq) and 9 (2.0 eq) were treated with $\mathrm{TiCl}_{4}$ (1.0 eq) in the presence of pyridine $(4.0 \mathrm{eq})$ in tetrahydrofuran (THF) at room temperature for $12 \mathrm{~h}, \mathbf{1 7}$ was obtained in $44 \%$ yield (Chart 3). ${ }^{4,5)}$

Having secured $\mathbf{1 7}$ in quantity, we turned our attention towards the synthesis of $\mathbf{1 1}$ (Chart 3). When $\mathbf{1 7}$ was treated with thiourea 8 in the presence of $\mathrm{HCl}$ according to the typical procedures of the three-component Biginelli reaction, the expected 2-thione product $\mathbf{1 1}$ was obtained in a low yield of $1 \%$. In contrast, the Atwal-Biginelli cyclocondensation reaction proceeded successfully with $\mathbf{1 7}$ and $S$-methylisothiourea hemisulfate salt 3 to afford 1,4-dihydro-4,4,6-trimethyl-2methylthiopyrimidine-5-carboxylate $\mathbf{1 2}$ and its 1,6-dihydro tautomer 13 as an inseparable mixture [12/13 (1.5:1)] in a combined yield of $89 \%$ (Chart 3). The structures of 12 and 13 were determined to be as depicted in Chart 3 by the NOESY experiment similar to that conducted with the tautomeric mixture of $\mathbf{1 5}$ and 16: for detail, see Experimental.

To see the concentration dependence of the tautomeric ratio of 12 to 13 , their combined concentration was changed from $1.1 \times 10^{-2}$ to $8.8 \times 10^{-2} \mathrm{M}$. The tautomeric ratio determined by ${ }^{1} \mathrm{H}-\mathrm{NMR}$ at $25^{\circ} \mathrm{C}$ remained unaffected at $1.5: 1$ throughout the concentrations varied. In contrast, the tautomeric ratio changed in a temperature-dependent manner. When the ${ }^{1} \mathrm{H}-\mathrm{NMR}$ spectra were measured at temperatures increased from 25 to $105^{\circ} \mathrm{C}$, the ratio decreased from $1.5: 1$ to $1.3: 1$. When the mixture was cooled to $25^{\circ} \mathrm{C}$, the ratio was restored to the original value. Although the change in the composition was not large over the range of temperatures tested, it was such the temperature-dependent interconvertibility that corroborated the tautomeric relationship between 12 and 13.

Now that the Knoevenagel-type condensation between the $\beta$-oxoester $\mathbf{1 0}$ and the ketone $\mathbf{9}$ had provided $\mathbf{1 7}$ in good yield under the Lehnert conditions, ${ }^{4,5)}$ we chose to apply those conditions to the synthesis of a range of 2-( $\mathrm{gem}$-disubstituted)methylene-3-oxoesters 4 . The Lehnert's procedures worked 
Table 1. Synthesis of 2-(gem-Disubstituted)methylene-3-oxoesters 4 under Lehnert Conditions for the Knoevenagel-Type Reaction ${ }^{a}$

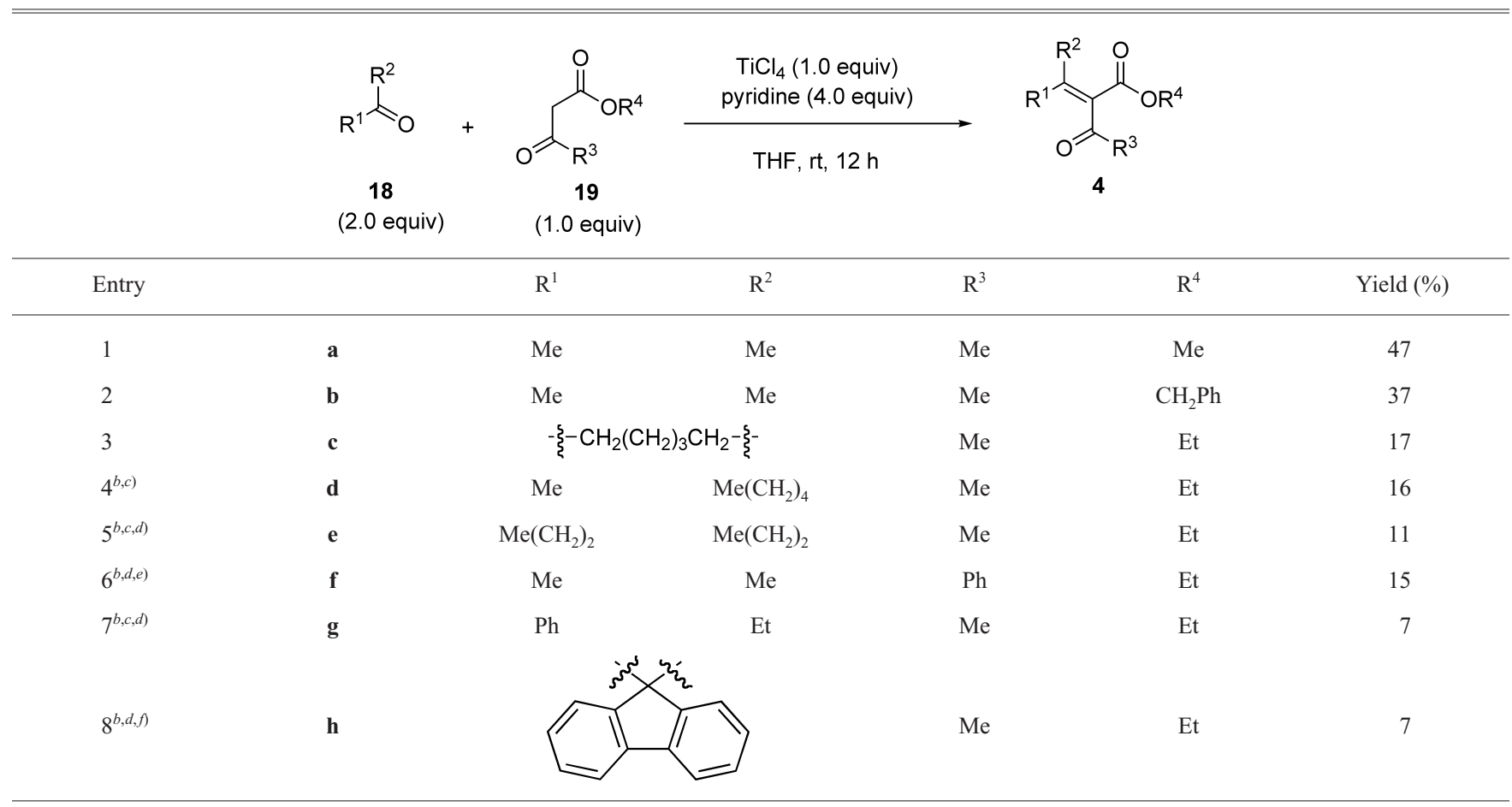

a) General conditions: a mixture of $\mathbf{1 8}(80 \mathrm{mmol}), \mathbf{1 9}(40 \mathrm{mmol}), \mathrm{TiCl}_{4}(40 \mathrm{mmol})$ and pyridine $(160 \mathrm{mmol})$ in $\mathrm{THF}(40 \mathrm{ml})$ was stirred at room temperature for $12 \mathrm{~h}$ under an atmosphere of argon unless otherwise specified. b) For $24 \mathrm{~h}$. c) $\mathbf{1 8}(1.0 \mathrm{eq})$ was used. $d$ ) $\mathrm{TiCl}_{4}\left(2.0\right.$ eq) was used. e) $\mathbf{1 8}(3.0 \mathrm{eq})$ and pyridine (6.0 eq) were used at $40{ }^{\circ} \mathrm{C}$. f) $\mathbf{1 8}(1.0 \mathrm{eq}), \mathbf{1 9}(1.5 \mathrm{eq}), \mathrm{TiCl}_{4}(3.0 \mathrm{eq})$ and pyridine $(6.0 \mathrm{eq})$ were used.

for the Knoevenagel-type condensation of the aliphatic ketones $\mathbf{1 8} \mathbf{a}-\mathbf{f}$ and the aromatic ketones $\mathbf{1 8 g}$ and $\mathbf{h}$ to afford the expected products $\mathbf{4 a - f}$, as summarized in Table 1.

Lehnert reported that ketones could undergo the Knoevenagel-type condensation with dialkyl malonate in the presence of $\mathrm{TiCl}_{4}$ and pyridine, ${ }^{4)}$ with the use of 3-oxoester being limited to the condensation reaction with aldehydes. ${ }^{5)}$ Thus, the experimental results in Table 1 are the first successful expansion of the Lehnert procedures to the Knoevenagel-type condensation between 3-oxoesters and ketones.

With a variety of 2-(gem-disubstituted)methylene-3-oxoesters $\mathbf{4}(\mathbf{1 7}, \mathbf{4} \mathbf{a}-\mathbf{h})$ in hand, the stage was set for assembling 1,4-dihydro-2-methylthio-4,4,6-trisubstituted pyrimidine $\mathbf{1}$ and its 1,6-dihydro tautomeric isomer 2, both of which had remained otherwise inaccessible. With all these substrates, 17 and $\mathbf{4 a}-\mathbf{h}$, the Atwal-Biginelli cyclocondensation reaction $\left[3\right.$ (1.2 eq), $\mathrm{NaHCO}_{3}$ (4.0 eq), DMF, $\left.65^{\circ} \mathrm{C}, 12 \mathrm{~h}\right)$ ] proceeded uneventfully to give 1,4-dihydro-2-methylthio pyrimidine $\mathbf{1}$ and its 1,6-dihydro tautomer $\mathbf{2}$ in a fair to good yield, as listed in Table 2.

What is worth making comments with respect to the tabulated results are as follows. In addition to ethyl ester $\mathbf{1 7}$ (Chart 3), the methyl and benzyl esters $\mathbf{4 a}$ and $\mathbf{4 b}$, respectively, were tolerated in the reaction, and the corresponding products $1 \mathbf{a} / \mathbf{2} \mathbf{a}$ and $\mathbf{1 b} / \mathbf{2} \mathbf{b}$ could be obtained without incident (entries 1, 2). Their alkylidene substituents being sterically demanding, $\mathbf{4 c}$ and $\mathbf{4 e}$ underwent olefin isomerization towards deconjunction under the basic conditions applied so that steric congestion can be relieved; however, when $\mathbf{3}$ was used in excess amounts, the cyclocondensation could compete with the isomerization to afford the respective prod- ucts $\mathbf{1 c} / \mathbf{2 c}$ and $\mathbf{1 e} / \mathbf{2 e}$ in acceptable yields (entries 3, 5). When starting from ethyl 2-isopropylidene-3-phenyl-3-oxopropanoate 4f, prepared from ethyl benzoylacetate 19f, a phenyl group could be installed at the 6-position of $\mathbf{1 f} / \mathbf{2} \mathbf{f}$ although 3 needed to be used in 3.0 eq to gain an acceptable yield (entry 6). A phenyl group could also be accommodated at the 4-position, as illustrated by $\mathbf{1 g} / \mathbf{2 g}$ (entry 7). Furthermore, a fluorenylidene group could be appended to the dihydropyrimidine skeleton, as shown by $\mathbf{1 h} / \mathbf{2 h}$ (entry 8 ).

\section{Conclusion}

In summary, it was demonstrated that alkyl 1,4-dihydro-2methylthio-4,4,6-trisubstituted pyrimidine-5-carboxylate $\mathbf{1}$ $(\mathbf{1 2}, \mathbf{1 a}-\mathbf{h})$ and its 1,6-dihydro tautomer $\mathbf{2}(\mathbf{1 3}, \mathbf{2} \mathbf{a}-\mathbf{h})$ could be assembled by applying the Atwal-Biginelli cyclocondensation reaction to 2-(gem-disubstituted)methylene-3-oxoesters $4(\mathbf{1 7}, \mathbf{4 a}-\mathbf{h})$, which, in turn, was prepared from ketones, 9 and $18 \mathbf{a}-\mathbf{h}$, and 3-oxoesters, 10 and $\mathbf{1 9 a}-\mathbf{h}$, by resorting to the Lehnert conditions for the Knoevenagel-type condensation. In view of the fact that all the dihydropyrimidine derivatives reported in this article are new in spite of their existence as inseparable tautomeric mixtures, the synthetic procedures developed in our laboratory should help to expand the dihydropyrimidine-based molecular diversity, which would impact the drug discovery program. ${ }^{6}$

\section{Experimental}

All melting points were determined with an AS ONE melting point apparatus ATM-02 without correction. IR spectra were measured on a JASCO FT/IR-6100. ${ }^{1} \mathrm{H}-\mathrm{NMR}$ spectra were recorded on a Bruker AVANCE ${ }^{\mathrm{TM}}$ III $600(600 \mathrm{MHz})$ with tetramethylsilane $(0 \mathrm{ppm})$ or dimethylsulfoxide $(2.49$ $\mathrm{ppm})$ as an internal standard. ${ }^{13} \mathrm{C}-\mathrm{NMR}$ spectra were recorded on a Bruker 
Table 2. Synthesis of Alkyl 1,4-Dihydro-2-methylthio-4,4,6-trisubstituted Pyrimidine-5-carboxylate 1 and Its 1,6-Dihydro Tautomer 2 under AtwalBiginelli Conditions ${ }^{a)}$<smiles>[R4]OC(=O)C([R])=C([R])C([R])=O</smiles>

\begin{tabular}{|c|c|c|c|c|c|c|c|}
\hline Entry & & $\mathrm{R}^{1}$ & $\mathrm{R}^{2}$ & $\mathrm{R}^{3}$ & $\mathrm{R}^{4}$ & Yield $^{b)}(\%)$ & $1 / 2^{c)}$ \\
\hline 1 & a & $\mathrm{Me}$ & $\mathrm{Me}$ & $\mathrm{Me}$ & $\mathrm{Me}$ & 84 & $1.5: 1$ \\
\hline 2 & b & $\mathrm{Me}$ & $\mathrm{Me}$ & $\mathrm{Me}$ & $\mathrm{CH}_{2} \mathrm{Ph}$ & 68 & $1.6: 1$ \\
\hline $3^{d)}$ & c & \multicolumn{2}{|c|}{$-\xi-\mathrm{CH}_{2}\left(\mathrm{CH}_{2}\right)_{3} \mathrm{CH}_{2}-\xi$} & $\mathrm{Me}$ & Et & 63 & $8.4: 1$ \\
\hline $4^{e)}$ & d & $\mathrm{Me}$ & $\operatorname{Me}\left(\mathrm{CH}_{2}\right)_{4}$ & $\mathrm{Me}$ & Et & 80 & $1.7: 1$ \\
\hline $5^{d)}$ & e & $\mathrm{Me}\left(\mathrm{CH}_{2}\right)_{2}$ & $\mathrm{Me}\left(\mathrm{CH}_{2}\right)_{2}$ & $\mathrm{Me}$ & Et & 63 & $1.8: 1$ \\
\hline $6^{d)}$ & f & $\mathrm{Me}$ & $\mathrm{Me}$ & $\mathrm{Ph}$ & Et & 73 & $1: 3.7$ \\
\hline $7^{f)}$ & g & $\mathrm{Ph}$ & Et & $\mathrm{Me}$ & Et & 63 & $3.0: 1$ \\
\hline 8 & h & & & $\mathrm{Me}$ & Et & 40 & $6.0: 1$ \\
\hline
\end{tabular}

a) General conditions: a mixture of $3(0.6 \mathrm{mmol}), 4(0.5 \mathrm{mmol}), \mathrm{NaHCO}_{3}(2.0 \mathrm{mmol})$ and $\mathrm{DMF}(1.0 \mathrm{ml})$ was stirred and heated at $65^{\circ} \mathrm{C}$ for $12 \mathrm{~h}$ under an atmosphere of argon unless otherwise specified. b) A combined yield of $\mathbf{1}$ and $\mathbf{2}$. c) Determined by ${ }^{1} \mathrm{H}-\mathrm{NMR}$ spectroscopy featuring NOE experiment. $d$ ) $\mathbf{3}$ (3.0 eq) was used. e) With $\mathbf{4 d}$ was used a $(2.5: 1)$ mixture of the $E / Z$ isomers. f) With $4 \mathrm{~g}$ was used a single geometric isomer although its configuration was unidentified.
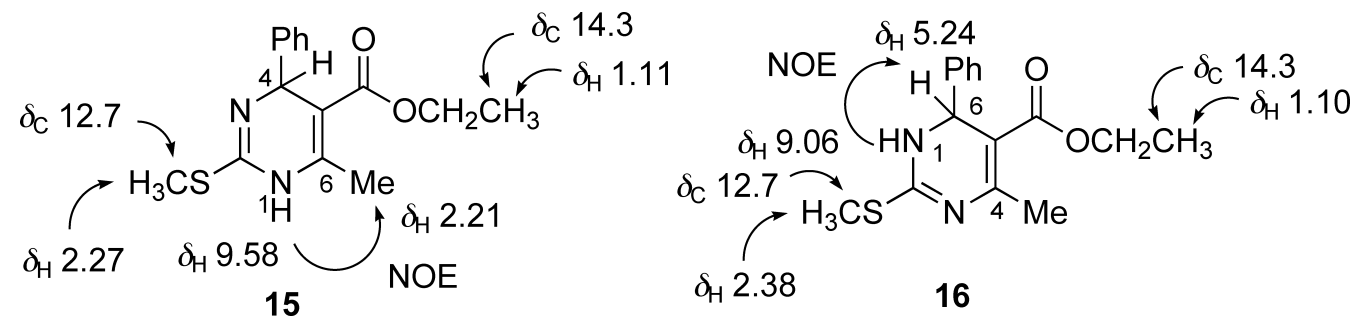

Fig. 2. NOE and HSQC Observed with $\mathbf{1 5}$ and $\mathbf{1 6}$

AVANCE ${ }^{\mathrm{TM}}$ III $600(150 \mathrm{MHz})$ with chloroform $(77.0 \mathrm{ppm})$ or dimethylsulfoxide $(39.7 \mathrm{ppm})$ as an internal standard. Mass spectra were recorded on a JEOL JMS-700. High-resolution mass spectroscopy (HRMS) was performed using a JEOL JMS-700. Column chromatography was performed on silica gel 60 (nacalai tesque, $70-230 \mathrm{mesh}$ ) using the indicated solvents. TLC was performed using pre-coated silica gel $60 \mathrm{~F}_{254}$ plates (Merck $\mathrm{KGaA}$ ) using the indicated solvents.

Ethyl 1,4-Dihydro-6-methyl-2-methylthio-4-phenyl Pyrimidine-5-carboxylate (15) and Ethyl 1,6-Dihydro-4-methyl-2-methylthio-6-phenyl Pyrimidine-5-carboxylate (16) Under an atmosphere of argon, a mixture of $S$-methylisothiourea hemisulfate $(3 ; 84 \mathrm{mg}, 0.6 \mathrm{mmol}), \mathbf{1 4}[109 \mathrm{mg}$, $0.5 \mathrm{mmol}, E / Z(1: 3.0)],{ }^{15)} \mathrm{NaHCO}_{3}(168 \mathrm{mg}, 2.0 \mathrm{mmol})$, and dry DMF $(1.0 \mathrm{ml})$ was heated at $60^{\circ} \mathrm{C}$ for $5 \mathrm{~h}$. To the reaction mixture was added EtOAc $(20 \mathrm{ml})$ followed by water $(10 \mathrm{ml})$, and the organic layer was separated. The aqueous layer was extracted with EtOAc $(20 \mathrm{ml} \times 2)$, and the combined organic layer and extracts were washed with water, brine, dried over $\mathrm{Na}_{2} \mathrm{SO}_{4}$, and concentrated under reduced pressure. The residue was purified by flash column chromatography [ $n$-hexane-EtOAc $(2: 1)]$ to give $\mathbf{1 5}$ and $\mathbf{1 6}$ as an inseparable mixture $(97 \mathrm{mg}, 0.33 \mathrm{mmol}, 67 \%)$ in a ratio of $2.2: 1$ in favor of 15. Colorless crystals. Melting point (mp) $168-171^{\circ} \mathrm{C}$ (chloroform). ${ }^{1} \mathrm{H}-\mathrm{NMR}$ [dimethyl sulfoxide (DMSO)- $d_{6}$ ] $\delta: 1.10(0.94 \mathrm{H}, \mathrm{t}, J=$ $7.2 \mathrm{~Hz}, 16), 1.11(2.06 \mathrm{H}, \mathrm{t}, J=7.2 \mathrm{~Hz}, 15), 2.21(2.06 \mathrm{H}, \mathrm{s}, 15), 2.26(0.94 \mathrm{H}$, $\mathrm{s}, \mathbf{1 6}), 2.27(2.06 \mathrm{H}, \mathrm{s}, \mathbf{1 5}), 2.38(0.94 \mathrm{H}, \mathrm{s}, \mathbf{1 6}), 3.94-4.05(2 \mathrm{H}, \mathrm{m}, \mathbf{1 5}+\mathbf{1 6})$, $5.24(0.31 \mathrm{H}, \mathrm{d}, J=3.0 \mathrm{~Hz}, \mathbf{1 6}), 5.50(0.69 \mathrm{H}, \mathrm{s}, \mathbf{1 5}), 7.15-7.35(5 \mathrm{H}, \mathrm{m}$, 15+16), $9.06(0.31 \mathrm{H}, \mathrm{d}, J=3.0 \mathrm{~Hz}, \mathbf{1 6}), 9.58(0.69 \mathrm{H}, \mathrm{s}, \mathbf{1 5})$. Structural as- signment was made unambiguously by NOESY experiment: With the major component, the significant NOE was observed between 1-NH proton $(\delta$ $9.58)$ and 6-methyl protons $(\delta 2.21)$ and as such, its structure was determined to be $\mathbf{1 5}$ (Fig. 2). With the minor component, the significant NOE was observed between 1-NH proton $(\delta 9.06)$ and 6-proton $(\delta 5.24)$ and as such, its structure was determined to be $\mathbf{1 6}$ (Fig. 2 ). ${ }^{13} \mathrm{C}-\mathrm{NMR}$ (150 MHz, DMSO$\left.d_{6}\right) \delta: 12.7$ (unresolved), 14.3 (unresolved), 17.7, 23.3, 53.3, 59.0, 59.2, $59.3,98.4,103.4,126.4,126.7,126.8,127.7,128.3,128.6,145.0,145.9$, $146.2,150.6,155.2,160.9,166.36,166.43$. The unresolved signals, $\delta 12.7$ and $\delta 14.3$, were further analyzed by heteronuclear single-quantum coherence (HSQC) experiment, which revealed that the signal at $\delta_{\mathrm{C}} 12.7$ was due to the $\mathrm{S}^{-\mathrm{CH}_{3}}$ of $\mathbf{1 5}$ and $\mathbf{1 6}$ because of its correlation to the signals at $\delta_{\mathrm{H}} 2.27$ $(\mathrm{s}, \mathbf{1 5})$ and $\delta_{\mathrm{H}} 2.38(\mathrm{~s}, \mathbf{1 6})$ and that $\delta_{\mathrm{C}} 14.3$ was due to the $\mathrm{OCH}_{2} \mathrm{CH}_{3}$ of 15 and 16 because of its correlation to attached to the signals $\delta_{\mathrm{H}} 1.11(\mathrm{t}, \mathbf{1 5})$ and $\delta_{\mathrm{H}} 1.10(\mathrm{t}, 16)$ (Fig. 2). IR (KBr) cm ${ }^{-1}: 3320,1657,1470,1281,1155$, 1109. Electron ionization (EI)-MS m/z: 290.1083 (Calcd for $\mathrm{C}_{15} \mathrm{H}_{18} \mathrm{~N}_{2} \mathrm{O}_{2} \mathrm{~S}$ : 290.1089). MS $m / z: 290\left(\mathrm{M}^{+}\right), 261,213,185$.

Ethyl 2-Acetyl-3-methylbut-2-enoate (17) According to the procedures reported by Lernert, ${ }^{4,5)}$ a solution of ethyl acetoacetate $(\mathbf{1 0} ; 5.2 \mathrm{~g}$, $40 \mathrm{mmol})$, acetone $(9 ; 5.8 \mathrm{ml}, 80 \mathrm{mmol})$, and pyridine $(12.6 \mathrm{~g}, 160 \mathrm{mmol})$ in dry THF $(15 \mathrm{ml})$ was added to an ice-cooled solution of $\mathrm{TiCl}_{4}(4.4 \mathrm{ml}, d$ $1.73,40 \mathrm{mmol})$ in dry THF $(25 \mathrm{ml})$ at $0{ }^{\circ} \mathrm{C}$ under an atmosphere of argon. The reaction mixture was stirred at room temperature for $12 \mathrm{~h}$, and EtOAc $(150 \mathrm{ml})$ and water $(30 \mathrm{ml})$ were added. The organic layer was separated, and the aqueous layer was extracted with EtOAc $(50 \mathrm{ml} \times 2)$. The combined or- 


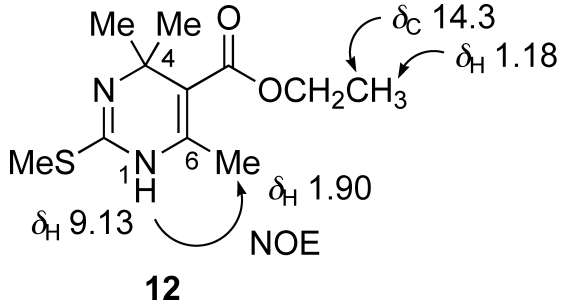

12

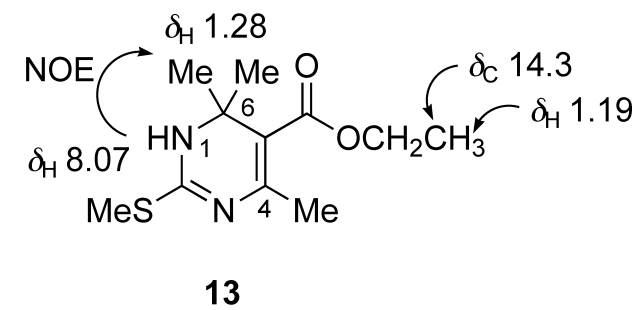

Fig. 3. NOE and HSQC Observed with 12 and 13

ganic layer and extracts were washed with saturated $\mathrm{NaHCO}_{3}$ aqueous solution, water, brine, dried over $\mathrm{Na}_{2} \mathrm{SO}_{4}$, and concentrated under reduced pressure. The residue was purified by flash column chromatography [ $n$ hexane-EtOAc $(20: 1)]$ to give $17(3.0 \mathrm{~g}, 17.6 \mathrm{mmol}, 44 \%)$, the ${ }^{1} \mathrm{H}-\mathrm{NMR}$ spectral data of which were identical to those reported ones. ${ }^{25)}$

2-(gem-Disubstituted)methylene-3-oxoester $(\mathbf{4 a}-\mathbf{h}) \quad$ The 2-(gem-disubstituted)methylene-3-oxoesters $\mathbf{4 a -} \mathbf{h}$, were all assembled under the conditions similar to those described for the synthesis of $\mathbf{1 7},,^{4,5}$ and below recorded are their isolated yield and their physicochemical and spectral data while the spectral data of $\mathbf{4 c}$ (yield: $17 \%$ ) and $\mathbf{4 f}$ (yield: $15 \%$ ) were identical to those reported ones. ${ }^{25)}$ Analysis and identification of the unresolved signal in the ${ }^{13} \mathrm{C}$-NMR spectrum of $\mathbf{4 h}$ were made based on HSQC experiment.

Methyl 2-Acetyl-3-methylbut-2-enoate (4a): Colorless oil. Yield: 47\%. ${ }^{1} \mathrm{H}-\mathrm{NMR}\left(\mathrm{CDCl}_{3}\right) \delta: 1.95(3 \mathrm{H}, \mathrm{s}), 2.11(3 \mathrm{H}, \mathrm{s}), 2.29(3 \mathrm{H}, \mathrm{s}), 3.77(3 \mathrm{H}, \mathrm{s})$. ${ }^{13} \mathrm{C}-\mathrm{NMR}\left(\mathrm{CDCl}_{3}\right) \delta: 22.9,23.2,30.6,51.7,131.8,153.6,166.0,200.6$. IR (neat) $\mathrm{cm}^{-1}: 2953,1727,1698,1632,1233$. Chemical ionization (CI)-MS $m / z: 156.1764$ (Calcd for $\mathrm{C}_{8} \mathrm{H}_{12} \mathrm{O}_{3}: 156.0787$ ). MS $m / z: 156\left(\mathrm{M}^{+}\right), 125$.

Benzyl 2-Acetyl-3-methylbut-2-enoate (4b): Colorless oil. Yield: $37 \%$. ${ }^{1} \mathrm{H}-\mathrm{NMR}\left(\mathrm{CDCl}_{3}\right) \delta: 1.95(3 \mathrm{H}, \mathrm{s}), 2.10(3 \mathrm{H}, \mathrm{s}), 2.23(3 \mathrm{H}, \mathrm{s}), 5.22(2 \mathrm{H}, \mathrm{s})$, $7.30-7.42(5 \mathrm{H}, \mathrm{m}) .{ }^{13} \mathrm{C}-\mathrm{NMR}\left(\mathrm{CDCl}_{3}\right) \delta: 23.0,23.3,30.7,66.5,128.2$, $128.3,128.5,131.8,135.3,154.0,165.4,200.3$. IR (neat) $\mathrm{cm}^{-1}: 1723,1698$, 1224, 1198. CI-MS m/z: 233.1189 (Calcd for $\mathrm{C}_{14} \mathrm{H}_{17} \mathrm{O}_{3}: 233.1177$ ). MS $m / z$ : $233\left(\mathrm{M}^{+}+\mathrm{H}\right), 125,91$.

Ethyl 2-Acetyl-3-methyloct-2-enoate (4d): Colorless oil. Yield: 16\%. An inseparable $(2.5: 1)$ mixture of the $E / Z$ isomers with theie structural assignment being impossible by the ordinary spectroscopic methods. ${ }^{1} \mathrm{H}-\mathrm{NMR}$ $\left(\mathrm{CDCl}_{3}\right) \delta: 0.89(0.86 \mathrm{H}, \mathrm{t}, J=7.2 \mathrm{~Hz}), 0.90(2.14 \mathrm{H}, \mathrm{t}, J=7.2 \mathrm{~Hz}), 1.25-1.37$ $(7 \mathrm{H}, \mathrm{m}), 1.45-1.53(2 \mathrm{H}, \mathrm{m}), 1.95(2.14 \mathrm{H}, \mathrm{s}), 2.09(0.86 \mathrm{H}, \mathrm{s}), 2.18(0.57 \mathrm{H}$, t, $J=7.8 \mathrm{~Hz}), 2.28(2.14 \mathrm{H}, \mathrm{s}), 2.29(0.86 \mathrm{H}, \mathrm{s}), 2.38(1.43 \mathrm{H}, \mathrm{t}, J=7.8 \mathrm{~Hz})$, $4.23(0.57 \mathrm{H}, \mathrm{q}, J=7.2 \mathrm{~Hz}), 4.24(1.43 \mathrm{H}, \mathrm{q}, J=7.2 \mathrm{~Hz}) .{ }^{13} \mathrm{C}-\mathrm{NMR}\left(\mathrm{CDCl}_{3}\right) \delta$ : $13.8,13.9,14.0,20.5,21.1,22.3,22.4,27.65,27.67,30.5,30.9,31.75$, $31.83,36.5,36.8,60.6,60.7,131.86,131.89,157.1,165.6,166.0,200.0$, 200.7. IR (neat) $\mathrm{cm}^{-1}: 2958,2933,1725,1703,1626,1227$. EI-MS $\mathrm{m} / z$ : 226.1578 (Calcd for $\mathrm{C}_{13} \mathrm{H}_{22} \mathrm{O}_{3}: 226.1569$ ). MS $m / z: 226\left(\mathrm{M}^{+}\right), 151,43$.

Ethyl 2-Acetyl-3-propylhex-2-enoate (4e): Colorless oil. Yield: 11\%. ${ }^{1} \mathrm{H}-\mathrm{NMR}\left(\mathrm{CDCl}_{3}\right) \delta: 0.94(3 \mathrm{H}, \mathrm{t}, J=7.2 \mathrm{~Hz}), 0.96(3 \mathrm{H}, \mathrm{t}, J=7.2 \mathrm{~Hz}), 1.30$ $(3 \mathrm{H}, \mathrm{t}, J=7.2 \mathrm{~Hz}), 1.45-1.55(6 \mathrm{H}, \mathrm{m}), 2.17(2 \mathrm{H}, \mathrm{t}, J=7.8 \mathrm{~Hz}), 2.28(3 \mathrm{H}, \mathrm{s})$, $2.38(2 \mathrm{H}, \mathrm{t}, J=7.8 \mathrm{~Hz}), 4.23(2 \mathrm{H}, \mathrm{q}, J=7.2 \mathrm{~Hz}) .{ }^{13} \mathrm{C}-\mathrm{NMR}\left(\mathrm{CDCl}_{3}\right) \delta: 14.1$, $14.3,14.4,21.86,21.93,30.9,35.7,36.4,60.7,132.0,160.8,165.8,200.5$. IR (neat) $\mathrm{cm}^{-1}: 2964,1724,1698,1615,1205$. CI-MS m/z: 227.1638 (Calcd for $\mathrm{C}_{13} \mathrm{H}_{23} \mathrm{O}_{3}$ : 227.1647). MS m/z: $227\left(\mathrm{M}^{+}+\mathrm{H}\right), 185,153$.

Ethyl 2-Acetyl-3-phenylpent-2-enoate (4g): Colorless oil. Yield: 7\%. A single geometric isomer with its configuration being unidentified. ${ }^{1} \mathrm{H}-\mathrm{NMR}$ $\left(\mathrm{CDCl}_{3}\right) \delta: 1.01(3 \mathrm{H}, \mathrm{t}, J=7.2 \mathrm{~Hz}), 1.32(3 \mathrm{H}, \mathrm{t}, J=7.2 \mathrm{~Hz}), 1.83(3 \mathrm{H}, \mathrm{s})$, $2.73(2 \mathrm{H}, \mathrm{q}, J=7.2 \mathrm{~Hz}), 4.28(2 \mathrm{H}, \mathrm{t}, J=7.2 \mathrm{~Hz}), 7.17-7.21(2 \mathrm{H}, \mathrm{m}), 7.35-$ $7.40(3 \mathrm{H}, \mathrm{m}) .{ }^{13} \mathrm{C}-\mathrm{NMR}\left(\mathrm{CDCl}_{3}\right) \delta: 12.4,14.0,29.5,30.8,61.0,127.8$, 128.5, 128.7, 133.7, 139.2, 157.3, 165.5, 201.5. IR (neat) $\mathrm{cm}^{-1}: 2979,1723$, 1703, 1233, 1204. EI-MS $m / z$ : 246.1255 (Calcd for $\mathrm{C}_{15} \mathrm{H}_{18} \mathrm{O}_{3}: 246.1256$ ). MS $m / z: 246\left(\mathrm{M}^{+}\right), 200,134,105,77$.

Ethyl 2-Fluoren-9-ylidene-3-oxobutanoate (4h): Yellow crystals. Yield: $7 \%$. mp $62-63^{\circ} \mathrm{C}$ (n-hexane). ${ }^{1} \mathrm{H}-\mathrm{NMR}\left(\mathrm{CDCl}_{3}\right) \delta: 1.40(3 \mathrm{H}, \mathrm{t}, J=7.2 \mathrm{~Hz})$, $2.62(3 \mathrm{H}, \mathrm{s}), 4.44(2 \mathrm{H}, \mathrm{q}, J=7.2 \mathrm{~Hz}), 7.19(1 \mathrm{H}, \mathrm{dt}, J=1.2,7.8 \mathrm{~Hz}), 7.23(1 \mathrm{H}$, $\mathrm{dt}, J=1.2,7.8 \mathrm{~Hz}), 7.38(1 \mathrm{H}, \mathrm{dt}, J=1.2,7.8 \mathrm{~Hz}), 7.39(1 \mathrm{H}, \mathrm{dt}, J=1.2$, $7.8 \mathrm{~Hz}), 7.49(1 \mathrm{H}, \mathrm{d}, J=7.8 \mathrm{~Hz}), 7.631(1 \mathrm{H}, \mathrm{d}, J=7.8 \mathrm{~Hz}), 7.632(1 \mathrm{H}, \mathrm{d}$, $J=7.8 \mathrm{~Hz}), 7.83(1 \mathrm{H}, \mathrm{d}, J=7.8 \mathrm{~Hz}) .{ }^{13} \mathrm{C}-\mathrm{NMR}\left(\mathrm{CDCl}_{3}\right) \delta: 14.0,31.1,62.2$, $119.7,119.9,125.4,125.7,127.6,127.7,130.6$ (unresolved), 131.8, 135.45, $135.50,140.1,141.4,141.5,165.2,201.2$. The unresolved signal, $\delta 130.6$ was further analyzed by HSQC experiment, which revealed that its correlation to the signals at $\delta_{\mathrm{H}} 7.38(\mathrm{dt})$ and $\delta_{\mathrm{H}} 7.39(\mathrm{dt})$. IR $(\mathrm{KBr}) \mathrm{cm}^{-1}: 1721$, 1688, 1584, 1226, 1210. EI-MS m/z: 292.1092 (Calcd for $\mathrm{C}_{19} \mathrm{H}_{16} \mathrm{O}_{3}$ : 292.1100). MS $m / z: 292\left(\mathrm{M}^{+}\right), 263,205,176$.
Ethyl 1,4-Dihydro-4,4,6-trimethyl-2-methylthio Pyrimidine-5-carboxylate (12) and Ethyl 1,6-Dihydro-4,6,6-trimethyl-2-methylthio Pyrimidine-5-carboxylate (13) Under an atmosphere of argon, a mixture of $S$-methylisothiourea hemisulfate $(\mathbf{3} ; 84 \mathrm{mg}, \quad 0.6 \mathrm{mmol}), \mathbf{1 7}$ (85 mg, $0.5 \mathrm{mmol})$, and $\mathrm{NaHCO}_{3}(168 \mathrm{mg}, 2.0 \mathrm{mmol})$ in dry DMF $(1.0 \mathrm{ml})$ was heated at $65^{\circ} \mathrm{C}$ for $12 \mathrm{~h}$. To the reaction mixture was added EtOAc $(20 \mathrm{ml})$ followed by water $(10 \mathrm{ml})$, and the organic layer was separated. The aqueous layer was extracted with EtOAc $(20 \mathrm{ml} \times 2)$, and the combined organic layer and extracts were washed with water, brine, dried over $\mathrm{Na}_{2} \mathrm{SO}_{4}$, and concentrated under reduced pressure. The residue was purified by flash column chromatography [ $n$-hexane-EtOAc $(4: 1)]$ to give $\mathbf{1 2}$ and $\mathbf{1 3}$ as an inseparable mixture $(108 \mathrm{mg}, 0.45 \mathrm{mmol}, 89 \%)$ in a ratio of $1.5: 1$ in favor of $\mathbf{1 2}$. Colorless crystals. mp $93-94{ }^{\circ} \mathrm{C}\left(n\right.$-hexane-EtOAc). ${ }^{1} \mathrm{H}-\mathrm{NMR}$ (DMSO- $d_{6}$ ) $\delta: 1.18(1.8 \mathrm{H}, \mathrm{t}, J=7.2 \mathrm{~Hz}, \mathbf{1 2}), 1.19(1.2 \mathrm{H}, \mathrm{t}, J=7.2 \mathrm{~Hz}, \mathbf{1 3}), 1.26(3.6 \mathrm{H}, \mathrm{s}$, 12), $1.28(2.4 \mathrm{H}, \mathrm{s}, \mathbf{1 3}), 1.90(1.8 \mathrm{H}, \mathrm{s}, \mathbf{1 2}), 1.94(1.2 \mathrm{H}, \mathrm{s}, 13), 2.24(1.8 \mathrm{H}, \mathrm{s}$, 12), $2.32(1.2 \mathrm{H}, \mathrm{s}, 13), 4.05(1.2 \mathrm{H}, \mathrm{q}, J=7.2 \mathrm{~Hz}, \mathbf{1 2}), 4.07(0.8 \mathrm{H}, \mathrm{q}$, $J=7.2 \mathrm{~Hz}, \mathbf{1 3}), 8.07(0.4 \mathrm{H}, \mathrm{s}, \mathbf{1 3}), 9.13(0.6 \mathrm{H}, \mathrm{s}, \mathbf{1 2})$. Structural assignment was made unambiguously by NOESY experiment: With the major component, the significant NOE was observed between 1-NH proton $(\delta 9.13)$ and 6-methyl protons $(\delta 1.90)$ and as such, its structure was determined to be $\mathbf{1 2}$ (Fig. 3). With the minor component, the significant NOE was observed between 1-NH $(\delta 8.07)$ and 6,6-dimethyl protons $(\delta 1.28)$ and as such, its structure was determined to be $\mathbf{1 3}$ (Fig. 3). ${ }^{13} \mathrm{C}-\mathrm{NMR}$ (DMSO- $d_{6}$ ) $\delta: 12.4$, 12.5, 14.3 (unresolved), 17.8, 23.2, 29.1, 31.0, 53.3, 55.8, 59.27, 59.33, $105.0,110.2,141.7,147.4,150.2,159.7,167.0,167.2$. The unresolved signal, $\delta 14.3$, was further analyzed by HSQC experiment, which revealed that the signal at $\delta_{\mathrm{C}} 14.3$ was due to the $\mathrm{OCH}_{2} \mathrm{CH}_{3}$ of $\mathbf{1 2}$ and $\mathbf{1 3}$ because of its correlation to the signals at $\delta_{\mathrm{H}} 1.18(\mathrm{t}, \mathbf{1 2})$ and $\delta_{\mathrm{H}} 1.19(\mathrm{~S}, 13)$ (Fig. 3). IR (KBr) $\mathrm{cm}^{-1}:$ 3154, 2929, 1698, 1643, 1609, 1485, 1311, 1171. EI-MS m/z: 242.1088 (Calcd for $\mathrm{C}_{11} \mathrm{H}_{18} \mathrm{~N}_{2} \mathrm{O}_{2} \mathrm{~S}: 242.1089$ ). MS m/z: $242\left(\mathrm{M}^{+}\right), 227,199$.

1,4-Dihydro-2-methylthio-4,4,6-trisubstituted Pyrimidine-5-carboxylates and 1,4-Dihydro-2-methylthio-4,6,6-trisubstituted Pyrimidine-5carboxylates $(\mathbf{1} \mathbf{a}-\mathbf{h} / \mathbf{2} \mathbf{a}-\mathbf{h}) \quad$ A tautomeric mixture of $\mathbf{1 a}-\mathbf{h} / \mathbf{2} \mathbf{a}-\mathbf{h}$ were synthesized according to the same procedures as described for the synthesis of the mixture of $\mathbf{1 2}$ and $\mathbf{1 3}$; below listed are their isolated yield and their physicochemical and spectral data for $\mathbf{1 a}-\mathbf{h} / \mathbf{2} \mathbf{a}-\mathbf{h}$. Analysis and identification of the unresolved signals in the ${ }^{13} \mathrm{C}-\mathrm{NMR}$ spectra of $\mathbf{1 a}-\mathbf{b} / \mathbf{2} \mathbf{a}-\mathbf{b}$, $\mathbf{1 d}-\mathbf{e} / \mathbf{2} \mathbf{d}-\mathbf{e}$ and $\mathbf{1 g} / \mathbf{2 g}$ were made based on HSQC experiment.

Methyl 1,4-Dihydro-4,4,6-trimethyl-2-methylthio Pyrimidine-5-carboxylate (1a) and Methyl 1,6-Dihydro-4,6,6-trimethyl-2-methylthio Pyrimidine-5-carboxylate (2a): Colorless crystals. Yield: $84 \%$. 1a/2a $=$ $1.5: 1 . \mathrm{mp} 85-86{ }^{\circ} \mathrm{C}$ ( $n$-hexane). ${ }^{1} \mathrm{H}-\mathrm{NMR}$ (DMSO- $\left.d_{6}\right) \delta: 1.26(3.6 \mathrm{H}, \mathrm{s}$, 1a), $1.28(2.4 \mathrm{H}, \mathrm{s}, \mathbf{2 a}), 1.90(1.8 \mathrm{H}, \mathrm{s}, \mathbf{1 a}), 1.95(1.2 \mathrm{H}, \mathrm{s}, \mathbf{2 a}), 2.25(1.8 \mathrm{H}, \mathrm{s}$, 1a), $2.33(1.2 \mathrm{H}, \mathrm{s}, \mathbf{2 a}), 3.59(1.8 \mathrm{H}, \mathrm{s}, \mathbf{1 a}), 3.60(1.2 \mathrm{H}, \mathrm{s}, \mathbf{2 a}), 8.10(0.4 \mathrm{H}, \mathrm{s}$, 2a), $9.16(0.6 \mathrm{H}, \mathrm{s}, 1 \mathrm{a})$. Exact structural assignment was made using NOESY experiment: With the major component, the significant NOE was observed between 1-NH proton $(\delta 9.16)$ and 6-methyl protons $(\delta 1.90)$ and as such, its structure was determined to be 1a (Fig. 4). With the minor component, the significant NOE was observed between 1-NH $(\delta 8.10)$ and 6,6-dimethyl protons $(\delta 1.28)$ and as such, its structure was determined to be $\mathbf{2 a}$ (Fig. 4). ${ }^{13} \mathrm{C}$-NMR (DMSO- $d_{6}$ ) $\delta: 12.5$ (unresolved), 17.8, 23.3, 29.1, 31.0, 50.7 (unresolved), 53.3, 55.8, 104.8, 110.0, 142.0, 147.3, 150.5, 159.9, 167.7. The unresolved signals, $\delta 12.5$ and $\delta 50.7$, were further analyzed by HSQC experiment, which revealed that the signal at $\delta_{\mathrm{C}} 12.5$ was due to the $\mathrm{S}-\mathrm{CH}_{3}$ of 1a and 2a because of its correlation to the signals at $\delta_{\mathrm{H}} 2.25(\mathrm{~s}, \mathbf{1 a})$ and $\delta_{\mathrm{H}}$ $2.33(\mathrm{~s}, \mathbf{2 a})$ and that $\delta_{\mathrm{C}} 50.7$ was due to the $\mathrm{OCH}_{3}$ of $\mathbf{1 a}$ and $\mathbf{2 a}$ because of its correlation to attached to the signals $\delta_{\mathrm{H}} 3.59(\mathrm{~s}, \mathbf{1 a})$ and $\delta_{\mathrm{H}} 3.60(\mathrm{~s}, \mathbf{2 a})$ (Fig. 4). IR (KBr) cm $\mathrm{cm}^{-1}$ : 2929, 1708, 1649, 1609, 1486, 1316, 1173. EI-MS $m / z$ : 228.0939 (Calcd for $\mathrm{C}_{10} \mathrm{H}_{16} \mathrm{~N}_{2} \mathrm{O}_{2} \mathrm{~S}: 228.0933$ ). MS $m / z$ : $228\left(\mathrm{M}^{+}\right), 213$, $m / z:$
181.

Benzyl 1,4-Dihydro-4,4,6-trimethyl-2-methylthio Pyrimidine-5-car- 


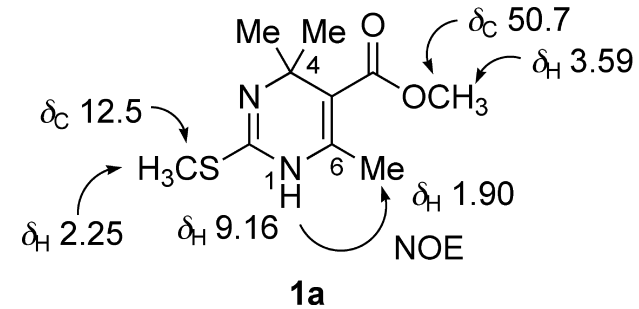

Fig. 4. NOE and HSQC Observed with 1a and 2a

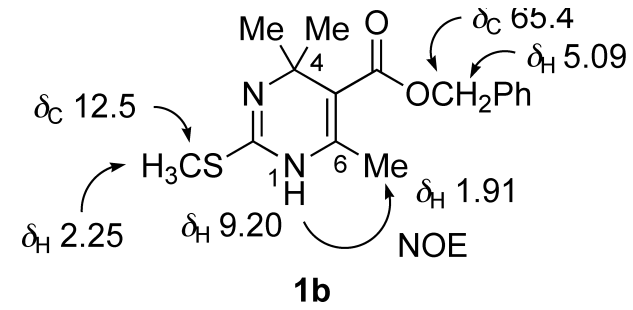

Fig. 5. NOE and HSQC Observed with $\mathbf{1 b}$ and $\mathbf{2 b}$<smiles>CCCCCCCCC1=C(C(=O)OCC)C2(CCCCC2)N=C(SC)N1</smiles>

Fig. 6. NOE Observed with 1c

boxylate (1b) and Benzyl 1,6-Dihydro-4,6,6-trimethyl-2-methylthio Pyrimidine-5-carboxylate (2b): Colorless oil. Yield: $68 \%$. 1b/2b=1.6: 1 . ${ }^{1} \mathrm{H}-\mathrm{NMR}\left(\mathrm{DMSO}-d_{6}\right) \delta: 1.27(3.69 \mathrm{H}, \mathrm{s}, \mathbf{1 b}), 1.28(2.31 \mathrm{H}, \mathrm{s}, 2 \mathbf{b}), 1.91$ $(1.85 \mathrm{H}, \mathrm{s}, \mathbf{1 b}), 1.96(1.15 \mathrm{H}, \mathrm{s}, \mathbf{2 b}), 2.25(1.85 \mathrm{H}, \mathrm{s}, \mathbf{1 b}), 2.33(1.15 \mathrm{H}, \mathrm{s}, \mathbf{2 b})$, $5.09(1.23 \mathrm{H}, \mathrm{s}, \mathbf{1 b}), 5.11(0.77 \mathrm{H}, \mathrm{s}, \mathbf{2 b}), 7.28-7.41(5 \mathrm{H}, \mathrm{m}, \mathbf{1 b}+\mathbf{2 b}), 8.13$ $(0.38 \mathrm{H}, \mathrm{s}, \mathbf{2 b}), 9.20(0.62 \mathrm{H}, \mathrm{s}, \mathbf{1 b})$. Exact structural assignment was made using NOESY experiment: with the major component, the significant NOE was observed between 1-NH proton $(\delta 9.20)$ and 6-methyl protons $(\delta 1.91)$ and as such, its structure was determined to be $\mathbf{1 b}$ (Fig. 5). With the minor component, the significant NOE was observed between 1-NH $(\delta 8.13)$ and 6,6-dimethyl protons $(\delta 1.28)$ and as such, its structure was determined to be 2b (Fig. 5). ${ }^{13} \mathrm{C}$-NMR (DMSO- $d_{6}$ ) $\delta$ : 12.5 (unresolved), 18.0, 23.4, 29.2, 31.1, 53.4, 55.9, 65.4 (unresolved), 104.6, 109.9, 128.2, 128.4, 128.7, 136.6, $142.6,147.4,151.1,160.1,167.0,167.1$. The unresolved signals, $\delta 12.5$ and $\delta 65.4$, were further analyzed by HSQC experiment, which revealed that the signal at $\delta_{\mathrm{C}} 12.5$ was due to the $\mathrm{S}-\mathrm{CH}_{3}$ of $\mathbf{1 b}$ and $\mathbf{2 b}$ because of its correlation to the signals at $\delta_{\mathrm{H}} 2.25(\mathrm{~s}, \mathbf{1 b})$ and $\delta_{\mathrm{H}} 2.33(\mathrm{~s}, \mathbf{2 b})$ and that $\delta_{\mathrm{C}} 65.4$ was due to the $\mathrm{OCH}_{2} \mathrm{Ph}$ of $\mathbf{1 b}$ and $\mathbf{2} \mathbf{b}$ because of its correlation to attached to the signals $\delta_{\mathrm{H}} 5.09(\mathrm{~s}, \mathbf{1 b})$ and $\delta_{\mathrm{H}} 5.11(\mathrm{~s}, \mathbf{2 b})$ (Fig. 5). IR (neat) $\mathrm{cm}^{-1}: 3322$, $1685,1522,1489,1313,1131$. EI-MS m/z: 304.1249 (Calcd for $\left.\mathrm{C}_{16} \mathrm{H}_{20} \mathrm{~N}_{2} \mathrm{O}_{2} \mathrm{~S}: 304.1245\right)$. MS m/z: $304\left(\mathrm{M}^{+}\right), 289,91$.

Ethyl 4-Methyl-2-methylthio-1,3-diazaspiro[5,5] undeca-2,5-diene 5Carboxylate (1c) and Ethyl 4-Methyl-2-methylthio-1,3-diazaspiro[5,5] undeca-2,4-diene 5-Carboxylate (2c): Colorless crystals. Yield: $63 \%$. $\mathbf{1 c} / \mathbf{2 c}=8.4: 1 . \mathrm{mp} 111-112{ }^{\circ} \mathrm{C}$ (n-hexane). ${ }^{1} \mathrm{H}-\mathrm{NMR}$ (DMSO- $\left.d_{6}\right) \delta: 1.10$ $1.90(13.32 \mathrm{H}, \mathrm{m}, \mathbf{1 c}+\mathbf{2 c}), 1.83(2.68 \mathrm{H}, \mathrm{s}, \mathbf{1 c}), 2.31(2.68 \mathrm{H}, \mathrm{s}, \mathbf{1 c}), 2.32$ $(0.32 \mathrm{H}, \mathrm{s}, \mathbf{2 c}), 4.06(1.79 \mathrm{H}, \mathrm{q}, J=7.2 \mathrm{~Hz}, \mathbf{1 c}), 4.09(0.21 \mathrm{H}, \mathrm{q}, J=7.2 \mathrm{~Hz}, \mathbf{2 c})$, $7.75(0.11 \mathrm{H}, \mathrm{s}, 2 \mathrm{c}), 9.10(0.89 \mathrm{H}, \mathrm{s}, 1 \mathrm{c})$. Exact structural assignment was made using NOESY experiment: with the major component, the significant NOE was observed between 1-NH proton $(\delta 9.10)$ and 6-methyl protons $(\delta$ 1.83 ) and as such, its structure was determined to be 1c (Fig. 6). ${ }^{13} \mathrm{C}-\mathrm{NMR}$ (DMSO- $d_{6}$ ) $\delta: 12.6,12.8,14.3,17.5,19.8,21.0,22.3,25.0,25.9,34.4,36.9$, $54.9,57.6,59.4,59.6,106.1,112.0,140.3,146.9,147.2,159.4,167.5$. IR $(\mathrm{KBr}) \mathrm{cm}^{-1}: 3293,2944,2922,1686,1656,1618,1482,1141$. EI-MS $\mathrm{m} / \mathrm{z}$ : 282.1408 (Calcd for $\mathrm{C}_{14} \mathrm{H}_{22} \mathrm{~N}_{2} \mathrm{O}_{2} \mathrm{~S}: 282.1402$ ). MS $m / z: 282\left(\mathrm{M}^{+}\right), 239,209$, 154.

Ethyl 1,4-Dihydro-4,6-dimethyl-2-methylthio-4-pentyl Pyrimidine-5-

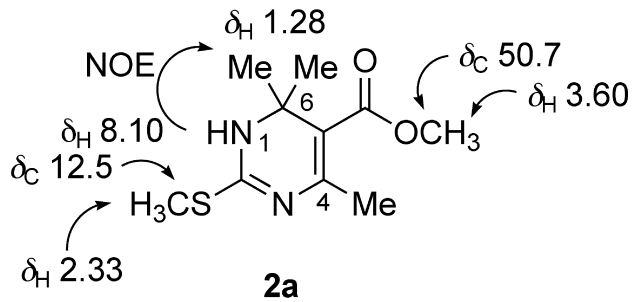

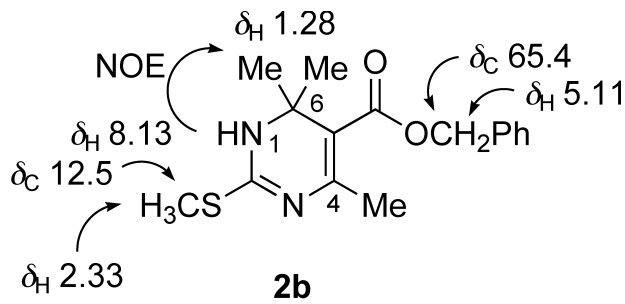

carboxylate (1d) and Ethyl 1,6-Dihydro-4,6-dimethyl-2-methylthio-6pentyl Pyrimidine-5-carboxylate (2d): Colorless oil. Yield: $80 \%$. $\mathbf{1 d} / \mathbf{2 d}=1.7: 1 .{ }^{1} \mathrm{H}-\mathrm{NMR}\left(\mathrm{DMSO}-d_{6}\right) \delta: 0.81(1.89 \mathrm{H}, \mathrm{t}, J=7.2 \mathrm{~Hz}, \mathbf{1 d}), 0.82$ $(1.11 \mathrm{H}, \mathrm{t}, J=7.2 \mathrm{~Hz}, \mathbf{2 d}), 1.00-1.38(7 \mathrm{H}, \mathrm{m}, \mathbf{1 d}+\mathbf{2 d}), 1.175(1.89 \mathrm{H}, \mathrm{t}$, $J=7.2 \mathrm{~Hz}, \mathbf{1 d}), 1.178(1.11 \mathrm{H}, \mathrm{t}, J=7.2 \mathrm{~Hz}, \mathbf{2 d}), 1.22(1.89 \mathrm{H}, \mathrm{s}, \mathbf{1 d}), 1.25$ $(1.11 \mathrm{H}, \mathrm{s}, \mathbf{2 d}), 1.82-1.94(1 \mathrm{H}, \mathrm{m}, \mathbf{1 d}+\mathbf{2 d}), 1.92(1.89 \mathrm{H}, \mathrm{s}, \mathbf{1 d}), 1.97$ $(1.11 \mathrm{H}, \mathrm{s}, \mathbf{2 d}), 2.24(1.89 \mathrm{H}, \mathrm{s}, \mathbf{1 d}), 2.32(1.11 \mathrm{H}, \mathrm{s}, \mathbf{2 d}), 4.00-4.09(2 \mathrm{H}, \mathrm{m}$, 1d+2d), $7.93(0.37 \mathrm{H}, \mathrm{s}, 2 \mathrm{~d}), 9.03(0.63 \mathrm{H}, \mathrm{s}, \mathbf{1 d})$. Exact structural assignment was made using NOESY experiment: with the major component, the significant NOE was observed between 1-NH proton ( $\delta$ 9.03) and 6-methyl protons $(\delta 1.92)$ and as such, its structure was determined to be 1d (Fig. 7). With the minor component, the significant NOE was observed between 1$\mathrm{NH}(\delta 7.93)$ and 6-methyl protons $(\delta 1.25)$ and as such, its structure was determined to be 2 d (Fig. 7). ${ }^{13} \mathrm{C}-\mathrm{NMR}$ (DMSO- $d_{6}$ ) $\delta$ : 12.4, 12.5, 14.1 (unresolved), 14.3 (unresolved), 17.9, 22.3, 23.5, 24.2, 24.7, 29.6, 30.9, 31.7, $31.8,40.9,42.5,56.9,59.1,59.2,59.3,102.9,107.8,142.8,147.3,151.5$, $160.0,167.2,167.4$. The unresolved signals, $\delta 14.1$ and $\delta 14.3$, were further analyzed by HSQC experiment, which revealed that the signal at $\delta_{\mathrm{C}} 14.1$ was due to the $\mathrm{CH}_{2} \mathrm{CH}_{2} \mathrm{CH}_{2} \mathrm{CH}_{2} \mathrm{CH}_{3}$ of $\mathbf{1 d}$ and $\mathbf{2 d}$ because of its correlation to the signals at $\delta_{\mathrm{H}} 0.81(\mathrm{t}, \mathbf{1 d})$ and $\delta_{\mathrm{H}} 0.82(\mathrm{t}, \mathbf{2 d})$ and that $\delta_{\mathrm{C}} 14.3$ was due to the $\mathrm{OCH}_{2} \mathrm{CH}_{3}$ of $\mathbf{1 d}$ and $\mathbf{2 d}$ because of its correlation to attached to the signals $\delta_{\mathrm{H}} 1.175(\mathrm{t}, \mathbf{1 d})$ and $\delta_{\mathrm{H}} 1.178(\mathrm{t}, \mathbf{2 d})$ (Fig. 7). IR (neat) $\mathrm{cm}^{-1}: 3313$, 2927, 1674, 1487, 1138. EI-MS m/z: 298.1720 (Calcd for $\mathrm{C}_{15} \mathrm{H}_{26} \mathrm{~N}_{2} \mathrm{O}_{2} \mathrm{~S}$ : 298.1715). MS m/z: $298\left(\mathrm{M}^{+}\right), 227,199$.

Ethyl 1,4-Dihydro-6-methyl-2-methylthio-4,4-dipropyl Pyrimidine-5carboxylate (1e) and Ethyl 1,6-Dihydro-4-methyl-2-methylthio-6,6dipropyl Pyrimidine-5-carboxylate (2e): Colorless oil. Yield: $63 \%$. $\mathbf{1 e} / \mathbf{2 e}=1.8: 1 .{ }^{1} \mathrm{H}-\mathrm{NMR}\left(\mathrm{DMSO}-d_{6}\right) \delta: 0.79(3.86 \mathrm{H}, \mathrm{t}, J=7.2 \mathrm{~Hz}, \mathbf{1 e}), 0.82$ $(2.14 \mathrm{H}, \mathrm{t}, J=7.2 \mathrm{~Hz}, \mathbf{2 e}), 1.09-1.34(9 \mathrm{H}, \mathrm{m}, \mathbf{1 e}+\mathbf{2 e}), 1.75-1.87(2 \mathrm{H}, \mathrm{m}$, $\mathbf{1 e}+\mathbf{2 e}), 1.93(1.93 \mathrm{H}, \mathrm{s}, \mathbf{1 e}), 1.99(1.07 \mathrm{H}, \mathrm{s}, \mathbf{2 e}), 2.24(1.93 \mathrm{H}, \mathrm{s}, \mathbf{1 e}), 2.31$ $(1.07 \mathrm{H}, \mathrm{s}, \mathbf{2 e}), 4.04(1.29 \mathrm{H}, \mathrm{q}, J=7.2 \mathrm{~Hz}, 1 \mathrm{e}), 4.05(0.71 \mathrm{H}, \mathrm{q}, J=7.2 \mathrm{~Hz}, \mathbf{2 e})$, $7.77(0.36 \mathrm{H}, \mathrm{s}, 2 \mathrm{e}), 8.90(0.64 \mathrm{H}, \mathrm{s}, \mathbf{1 e})$. Exact structural assignment was made using NOESY experiment: with the major component, the significant NOE was observed between 1-NH proton $(\delta 8.90)$ and 6-methyl protons $(\delta$ 1.93 ) and as such, its structure was determined to be 1e (Fig. 8). With the minor component, the significant NOE was observed between 1-NH $(\delta 7.77)$ and 6-methylene protons $(\delta 1.75-1.87)$ and as such, its structure was determined to be $2 \mathrm{e}$ (Fig. 8). ${ }^{13} \mathrm{C}-\mathrm{NMR}$ (DMSO- $d_{6}$ ) $\delta$ : $12.2,12.3,14.3,14.4,14.6$ (unresolved), 17.8, 18.01, 18.03, 23.8, 44.1, 45.3, 59.06, 59.13, 60.7, 63.0, $100.4,105.0,143.7,147.2,152.8,160.3,167.4,167.5$. The unresolved signal, $\delta 14.6$, was further analyzed by HSQC experiment, which revealed that the signal at $\delta_{\mathrm{C}} 14.6$ was due to the $\mathrm{CH}_{2} \mathrm{CH}_{2} \mathrm{CH}_{3}$ of $1 \mathrm{e}$ and $2 \mathrm{e}$ because of its correlation to the signals at $\delta_{\mathrm{H}} 0.79(\mathrm{t}, 1 \mathrm{e})$ and $\delta_{\mathrm{H}} 0.82(\mathrm{t}, 2 \mathrm{e})$ (Fig. 8). IR (neat) $\mathrm{cm}^{-1}: 2958,1689,1668,1658,1499,1279,1139$. EI-MS $\mathrm{m} / \mathrm{z}$ : 298.1714 (Calcd for $\mathrm{C}_{15} \mathrm{H}_{26} \mathrm{~N}_{2} \mathrm{O}_{2} \mathrm{~S}: 298.1715$ ). MS $m / z: 298\left(\mathrm{M}^{+}\right), 255,227$.

Ethyl 1,4-Dihydro-4,4-dimethyl-2-methylthio-6-phenyl Pyrimidine-5carboxylate (1f) and Ethyl 1,6-Dihydro-6,6-dimethyl-2-methylthio-4phenyl Pyrimidine-5-carboxylate (2f): Colorless crystals. Yield: $73 \%$. $\mathbf{1 f} / \mathbf{2 f}=1: 3.7 . \mathrm{mp} 132-134{ }^{\circ} \mathrm{C}\left(n\right.$-hexane-EtOAc). ${ }^{1} \mathrm{H}-\mathrm{NMR}$ (DMSO- $\left.d_{6}\right) \delta$ : $0.67(0.64 \mathrm{H}, \mathrm{t}, J=7.2 \mathrm{~Hz}, \mathbf{1 f}), 0.77(2.36 \mathrm{H}, \mathrm{t}, J=7.2 \mathrm{~Hz}, \mathbf{2 f}), 1.33(1.28 \mathrm{H}, \mathrm{s}$, 


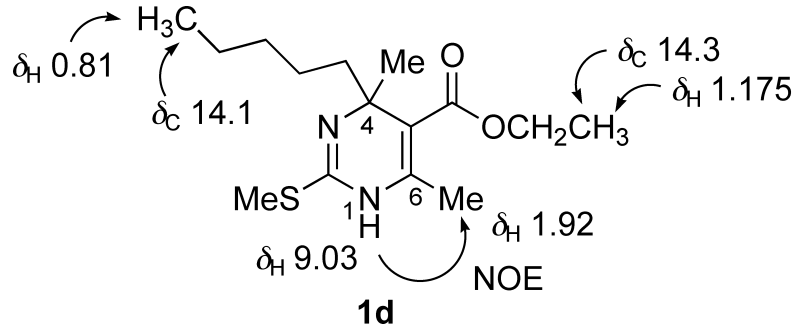

Fig. 7. NOE and HSQC Observed with $\mathbf{1 d}$ and $\mathbf{2 d}$
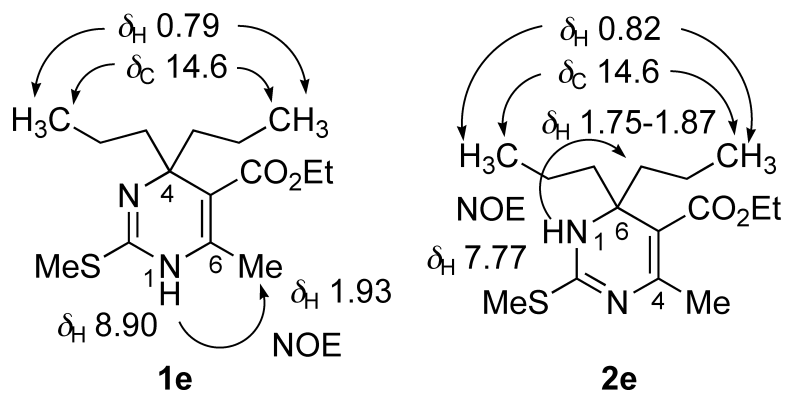

Fig. 8. NOE and HSQC Observed with $1 \mathbf{e}$ and $\mathbf{2 e}$

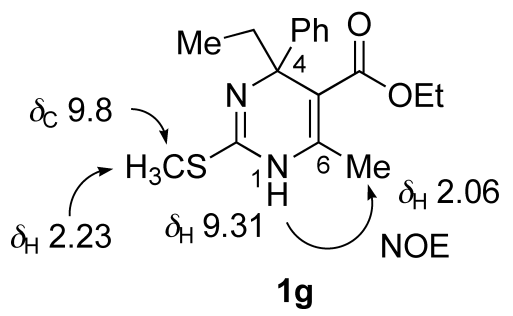

Fig. 10. NOE and HSQC Observed with $\mathbf{1 g}$ and $\mathbf{2 g}$

1f), $1.34(4.72 \mathrm{H}, \mathrm{s}, \mathbf{2 f}), 2.29(0.64 \mathrm{H}, \mathrm{s}, \mathbf{1 f}), 2.38(2.36 \mathrm{H}, \mathrm{s}, \mathbf{2 f}), 3.70(0.43 \mathrm{H}$, q, $J=7.2 \mathrm{~Hz}, \mathbf{1 f}), 3.79(1.57 \mathrm{H}, \mathrm{q}, J=7.2 \mathrm{~Hz}, \mathbf{2 f}), 7.21(0.43 \mathrm{H}, \mathrm{dd}, J=1.8$, $7.8 \mathrm{~Hz}, \mathbf{1 f}), 7.25-7.34(3.93 \mathrm{H}, \mathrm{m}, \mathbf{2 f}), 7.35-7.45(0.64 \mathrm{H}, \mathrm{m}, \mathbf{1 f}), 8.28$ $(0.79 \mathrm{H}, \mathrm{s}, \mathbf{2 f}), 9.52(0.21 \mathrm{H}, \mathrm{s}, \mathbf{1 f})$. Exact structural assignment was made using NOESY experiment: with the major component, the significant NOE was observed between 1 -NH proton $(\delta 8.28)$ and 6,6 -methyl protons $(\delta$ 1.34 ) and as such, its structure was determined to be 2 f (Fig. 9). With the minor component, the significant NOE was observed between 1-NH $(\delta 9.52)$ and 6-phenyl protons $(\delta 7.21)$ and as such, its structure was determined to be 1f (Fig. 9). ${ }^{13} \mathrm{C}-\mathrm{NMR}$ (DMSO- $d_{6}$ ) $\delta: 12.7,12.8,13.46,13.53,28.6,30.2$, $53.2,55.8,59.3,59.6,107.0,110.9,127.7,127.9,128.0,128.2,128.3$, $129.1,135.3,140.8,141.4,147.8,148.9,159.7,167.5,167.9$. IR $(\mathrm{KBr})$ $\mathrm{cm}^{-1}: 2976,1702,1535,1499,1326,1194,1051$. EI-MS (EI) $\mathrm{m} / z: 304.1250$ (Calcd for $\mathrm{C}_{16} \mathrm{H}_{20} \mathrm{~N}_{2} \mathrm{O}_{2} \mathrm{~S}: 304.1245$ ). MS (EI) $m / z: 304\left(\mathrm{M}^{+}\right.$), 289, 261.

Ethyl 4-Ethyl-1,4-dihydro-6-methyl-2-methylthio-4-phenyl Pyrimidine-5-carboxylate (1g) and Ethyl 6-Ethyl-1,6-dihydro-4-methyl-2methylthio-6-phenyl Pyrimidine-5-carboxylate (2g): Colorless crystals. Yield: $63 \% . \mathbf{1 g} / \mathbf{2 g}=3.0: 1 . \mathrm{mp} 149-150{ }^{\circ} \mathrm{C}$ ( $n$-hexane-EtOAc). ${ }^{1} \mathrm{H}-\mathrm{NMR}$ $\left(\right.$ DMSO- $\left.d_{6}\right) \delta: 0.80(2.25 \mathrm{H}, \mathrm{t}, J=7.2 \mathrm{~Hz}, \mathbf{1 g}), 0.90(0.75 \mathrm{H}, \mathrm{t}, J=7.2 \mathrm{~Hz}, 2 \mathrm{~g})$ $0.94(2.25 \mathrm{H}, \mathrm{t}, J=7.2 \mathrm{~Hz}, \mathbf{1 g}), 0.95(0.75 \mathrm{H}, \mathrm{t}, J=7.2 \mathrm{~Hz}, \mathbf{2 g}), 1.80(0.25 \mathrm{H}$, dq, $J=13.8,7.2 \mathrm{~Hz}, \mathbf{2 g}), 1.87(0.75 \mathrm{H}, \mathrm{dq}, J=7.2,13.2 \mathrm{~Hz}, \mathbf{1 g}), 2.06(2.25 \mathrm{H}$, s, 1g), $2.13(0.75 \mathrm{H}, \mathrm{s}, \mathbf{2 g}), 2.23(2.25 \mathrm{H}, \mathrm{s}, \mathbf{1 g}), 2.34(0.75 \mathrm{H}, \mathrm{s}, \mathbf{2 g}), 2.36$ $2.47(1 \mathrm{H}, \mathrm{m}, \mathbf{1 g}+\mathbf{2 g}), 3.79-3.92(2 \mathrm{H}, \mathrm{m}, \mathbf{1 g}+\mathbf{2 g}), 7.11(0.75 \mathrm{H}, \mathrm{t}$, $J=7.2 \mathrm{~Hz}, \mathbf{1 g}), 7.19(0.25 \mathrm{H}, \mathrm{t}, J=7.2 \mathrm{~Hz}, \mathbf{2 g}), 7.23(1.5 \mathrm{H}, \mathrm{t}, J=7.2 \mathrm{~Hz}, \mathbf{1 g})$, $7.30(0.5 \mathrm{H}, \mathrm{t}, J=7.2 \mathrm{~Hz}, \mathbf{2 g}), 7.31(1.5 \mathrm{H}, \mathrm{d}, J=7.2 \mathrm{~Hz}, 1 \mathrm{~g}), 7.37(0.5 \mathrm{H}, \mathrm{d}$, $J=7.2 \mathrm{~Hz}, \mathbf{2 g}), 8.45(0.25 \mathrm{H}, \mathrm{s}, \mathbf{2 g}), 9.31(0.75 \mathrm{H}, \mathrm{s}, \mathbf{1 g})$. Exact structural assignment was made using NOESY experiment: with the major component, the significant NOE was observed between 1-NH proton $(\delta 9.31)$ and 6methyl protons $(\delta 2.06)$ and as such, its structure was determined to be $\mathbf{1 g}$ (Fig. 10). With the minor component, the significant NOE was observed between 1-NH $(\delta 8.45)$ and 6-methylene protons $(\delta 1.80)$ and as such, its structure was determined to be $\mathbf{2 g}$ (Fig. 10 ). ${ }^{13} \mathrm{C}-\mathrm{NMR}$ (DMSO- $d_{6}$ ) $\delta: 9.8$ (unresolved), 12.4, 12.5, 13.95, 13.98, 18.10, 24.0, 31.3, 32.9, 59.0, 59.1, $62.2,64.9,101.0,105.6,125.8,126.4,126.7,126.8,127.5,127.9,144.3$,

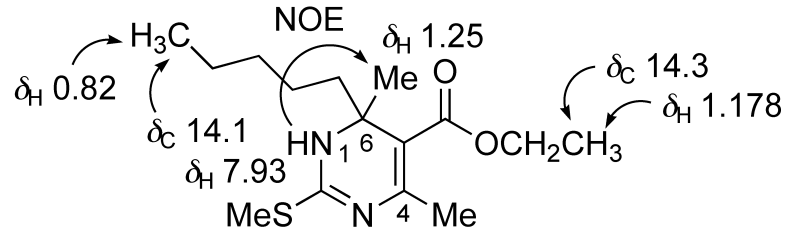

2d

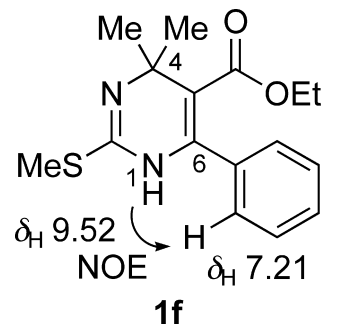<smiles>CCCCCCCCCCCCCCCCCSC1=NC(c2ccccc2)=C(C(=O)OCC)C(C)(C)N1</smiles>

Fig. 9. NOE Observed with $\mathbf{1 f}$ and $\mathbf{2 f}$

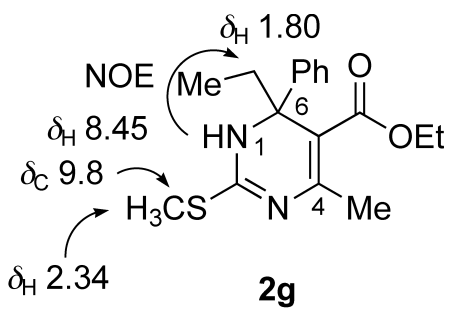<smiles>CCOC(=O)C1=C(N(C)C)NC(SC)=NC12c1ccccc1-c1ccccc12</smiles>

Fig. 11. NOE Observed with $\mathbf{1 h}$

$147.9,149.0,150.3,153.5,159.8,166.95,167.0$. The unresolved signal, $\delta$ 9.8, was further analyzed by HSQC experiment, which revealed that the signal at $\delta_{\mathrm{C}} 9.8$ was due to the S- $\mathrm{CH}_{3}$ of $\mathbf{1 g}$ and $\mathbf{2} \mathbf{g}$ because of its correlation to the signals at $\delta_{\mathrm{H}} 2.23(\mathrm{~s}, \mathbf{1 g})$ and $\delta_{\mathrm{H}} 2.34(\mathrm{~s}, \mathbf{2 g})$ (Fig. 10). IR $(\mathrm{KBr}) \mathrm{cm}^{-1}$ : 3264, 2969, 1664, 1583, 1530, 1462, 1314, 1073. EI-MS m/z: 318.1401 (Calcd for $\mathrm{C}_{17} \mathrm{H}_{22} \mathrm{~N}_{2} \mathrm{O}_{2} \mathrm{~S}: 318.1400$ ). MS $m / z: 318\left(\mathrm{M}^{+}\right), 289,261$.

Ethyl 6-Methyl-2-methylthio Spiro $\left[9^{\prime} H\right.$-fluorene-9',4-1,4-dihydropyrimidine] 5-Carboxylate (1h) and Ethyl 4-Methyl-2-methylthio Spiro $\left[9^{\prime} \boldsymbol{H}\right.$-fluorene-9',6-1,6-dihydropyrimidine] 5-Carboxylate (2h): Yellow amorphous solid. Yield: $40 \%$. $\mathbf{1 h} / \mathbf{2 h}=6.0: 1$. mp $57-63^{\circ} \mathrm{C}$. ${ }^{1} \mathrm{H}-\mathrm{NMR}$ (DMSO- $\left.d_{6}\right) \delta: 0.35(2.57 \mathrm{H}, \mathrm{t}, J=7.2 \mathrm{~Hz}, \mathbf{1 h}), 0.36(0.43 \mathrm{H}, \mathrm{t}, J=7.2 \mathrm{~Hz}, \mathbf{2 h})$, $2.02(2.57 \mathrm{H}, \mathrm{s}, \mathbf{1 h}), 2.23(2.57 \mathrm{H}, \mathrm{s}, \mathbf{1 h}), 2.27(0.43 \mathrm{H}, \mathrm{s}, \mathbf{2 h}), 2.40(0.43 \mathrm{H}, \mathrm{s}$, 2h), $3.30(1.71 \mathrm{H}, \mathrm{q}, J=7.2 \mathrm{~Hz}, \mathbf{1 h}), 3.33(0.29 \mathrm{H}, \mathrm{q}, J=7.2 \mathrm{~Hz}, \mathbf{2 h}), 7.19$ $7.26(3.42 \mathrm{H}, \mathrm{m}, \mathbf{1 h}), 7.26-7.29(0.29 \mathrm{H}, \mathrm{m}, \mathbf{2 h}), 7.30(1.71 \mathrm{H}, \mathrm{dt}, J=1.2$ $7.2 \mathrm{~Hz}, 1 \mathbf{h}), 7.36(0.29 \mathrm{H}, \mathrm{dt}, J=1.2,7.2 \mathrm{~Hz}, \mathbf{2 h}), 7.40(0.29 \mathrm{H}, \mathrm{d}, J=7.8 \mathrm{~Hz}$, 2h), $7.71(1.71 \mathrm{H}, \mathrm{d}, J=7.2 \mathrm{~Hz}, \mathbf{1 h}), 7.74(0.29 \mathrm{H}, \mathrm{d}, J=7.2 \mathrm{~Hz}, \mathbf{2 h}), 8.75$ $(0.14 \mathrm{H}, \mathrm{s}, \mathbf{2 h}), 9.73(0.86 \mathrm{H}, \mathrm{s}, \mathbf{1 h})$. Exact structural assignment was made using NOESY experiment: with the major component, the significant NOE was observed between 1-NH proton $(\delta 9.73)$ and 6-methyl protons $(\delta 2.23)$ and as such, its structure was determined to be $\mathbf{1 h}$ (Fig. 11). ${ }^{13} \mathrm{C}-\mathrm{NMR}$ 
$\left(\mathrm{DMSO}_{-}{ }_{6}\right) \delta: 12.4,12.7,13.0,13.1,18.1,24.0,58.4,58.5,65.7,69.4,99.5$, $105.0,119.7,120.0,124.1,124.3,127.7,127.9,128.3,128.8,139.3,139.5$, 146.6, 150.0, 152.3, 155.0, 155.2, 161.0, 165.8, 165.9. IR $\left(\mathrm{CHCl}_{3}\right) \mathrm{cm}^{-1}$ : 3298, 1676, 1648, 1483, 1165, 1106. EI-MS m/z: 364.1249 (Calcd for $\left.\mathrm{C}_{21} \mathrm{H}_{20} \mathrm{~N}_{2} \mathrm{O}_{2} \mathrm{~S}: 364.1245\right)$. MS m/z: $364\left(\mathrm{M}^{+}\right), 291$.

Acknowledgements Y. N. thanks Prof. Hidetsura Cho, Graduate School of Pharmaceutical Sciences, Graduate School of Sciences, Tohoku University for a helpful discussion in a seminal stage of this work.

\section{References and Notes}

1) O'Reilly B. C., Atwal K. S., Heterocycles, 26, 1185-1188 (1987).

2) Atwal K. S., O'Reilly B. C., Gougoutas J. Z., Malley M. F., Heterocycles, 26, 1189-1192 (1987).

3) Cho H., Shima K., Hayashimatsu M., Ohnaka Y., Mizuno A., Takeuchi Y., J. Org. Chem., 50, 4227-4230 (1985).

4) Lehnert W., Tetrahedron, 29, 635-638 (1973)

5) Lehnert W., Tetrahedron, 28, 663-666 (1972).

6) Our synthetic approaches to $\mathbf{5 a}$ and $\mathbf{5 b}$ will be discussed and published separately in due course.

7) Atwal K. S., Swanson B. N., Unger S. E., Floyd D. M., Moreland S. Hedberg A., O’Reilly B. C., J. Med. Chem., 34, 806-811 (1991).

8) DeBonis S., Simorre J.-P., Crevel I., Lebeau L., Skoufias D. A., Blangy A., Ebel C., Gans P., Cross R., Hackney D. D., Wade R. H., Kozielski F., Biochemistry, 42, 338-349 (2003).

9) Maliga Z., Kapoor T. M., Mitchison T. J., Chem. Biol., 9, 989-996 (2002).

10) Mayer T. U., Kapoor T. M., Haggarty S. J., King R. W., Schreiber S. L., Mitchison T. J., Science, 286, 971—974 (1999).

11) Kappe C. O., Stadler A., Org. React., 63, 1-116 (2004).

12) Tabouazat M., Louzi A. E., Ahmar M., Cazes B., Synlett, 2495-2499 (2008).

13) Bertozzi F., Gundersen B. V., Gustafsson M., Olsson R., Org. Lett., 5, $1551-1554$ (2003).
14) Marzinzik A. L., Felder E. R., J. Org. Chem., 63, 723 -727 (1998).

15) Anaç O., Sezer Ö., Candan Ö., Güngör F. Ş., Cansever M. Ş., Tetrahedron Lett., 49, 1062-1065 (2008).

16) Matloobi M., Kappe C. O., J. Comb. Chem., 9, 275-284 (2007).

17) Kappe C. O., Roschger P., J. Heterocycl. Chem., 26, 55-64 (1989).

18) Tietze L. F., Beifuss U., "Comprehensive Organic Synthesis," Vol. II, Chap. 1.11, ed. by Trost B. M., Pergamon Press, Oxford, 1991, pp. $341-394$

19) According to a literature survey conducted online, there were intramolecular successes of the Knoevenegel-type condensation between 3 -oxoesters and ketones, as exemplified by references 20 and 21, while any of them has no relevance to the present case. As regards an intermolecular version of such the condensation reactions, there were few that could be applied to the transformation in question for the following reasons: (1) less availability of the condensation catalysts, ${ }^{22,23)}(2)$ structural limitation on an electrophile employed. ${ }^{24)}$

20) Kikuchi H., Sasaki K., Sekiya J., Maeda Y., Amagai A., Kubohara Y., Oshima Y., Bioorg. Med. Chem., 12, 3203-3214 (2004).

21) Chiba S., Kitamura M., Narasaka K., J. Am. Chem. Soc., 128, 69316937 (2006).

22) For the catalytic use of fused zinc chloride, which should be prepared prior to immediate use, in the condensation of ethyl acetoacetate with acetone, see: Bennani Y. L., Boehm M. F., J. Org. Chem., 60, 11951200 (1995) and references therein.

23) For an attempt to apply a designer's zeolite catalyst to the condensation of ethyl acetoacetate with acetophenone, which ended in less success in terms of isolated yield of the product, see: Saravanamurgan S., Palanichamy M., Hartmann M., Murugesan V., Appl. Catal. A Gen., 298, 8-15 (2006).

24) For the condensation of ethyl acetoacetate with an exotic ketone, 21dimethylaminomethyleneprogesterone, through the catalytic agency of ammonium acetate, see: Mohareb R. M., Hana H. Y., Acta Pharm., 58, $29-42$ (2008).

25) Russel G. A., Mudryk B., Jawdosiuk M., Synthesis, 62—63 (1981). 